\title{
Malagasy Polka Dot Moths (Noctuoidea: Erebidae: Arctiinae: Syntomini) of Ambohitantely - endemism in the most important relict of Central Plateau rainforest in Madagascar.
}

\author{
Marcin Wiorek $^{1}{ }^{1}$ Kamila Malik $^{2}{ }^{2}$ David Lees $^{3}$, Lukasz Przybyłowicz $^{\text {Corresp. } 1}$ \\ ${ }^{1}$ Department of Invertebrate Zoology, Institute of Systematics and Evolution of Animals, Polish Academy of Sciences, Kraków, Poland \\ 2 Department of Invertebrate Evolution, Institute of Zoology and Biomedical Research, Jagiellonian University, Kraków, Poland \\ 3 Department of Life Sciences, Natural History Museum, London, United Kingdom \\ Corresponding Author: Łukasz Przybyłowicz \\ Email address: lukasz@isez.pan.krakow.pl
}

Malagasy Syntomini (Polka Dot Moths) are one of the largest endemic lineages of Lepidoptera on the island, belonging to the Tiger Moth subfamily (Arctiinae). This diverse radiation comprises nearly 100 valid described species that share a single ancestor. Despite a monograph in 1964 by Paul Griveaud, systematics of the group greatly needs modern revision, and their distribution on the island is still poorly known. This contribution concerns the diversity of Syntomini of the Réserve Spéciale d'Ambohitantely, which protects the largest remaining but already highly fragmented vestige Central Plateau rainforest in Madagascar. Here we provide an annotated checklist of the eight species occurring in the Reserve. Two species are recorded from the forest for the first time, while five endemics are still now known only from Ambohitantely. We also describe for the first time the female of Thyrosticta vestigii Griveaud, 1964 and of Maculonaclia tampoketsya Griveaud, 1969, as well as a yellow morphotype of Thyrosticta dilata Griveaud, 1964, and we redescribe and illustrate the genitalia of remaining species. The significance of such colour pattern variation in aposematic moths and the role of this Reserve as a local centre of diversity of Malagasy Syntomini together with its importance in the protection of the biodiversity of Madagascar are discussed. 


\section{Malagasy Polka Dot Moths (Noctuoidea: Erebidae:}

3 Arctiinae: Syntomini) of Ambohitantely - endemism in 4 the most important relict of Central Plateau rainforest 5 in Madagascar.

Marcin Wiorek $^{1}$, Kamila Malik ${ }^{2}$, David C. Lees ${ }^{3}$, Łukasz Przybyłowicz $^{1}$

${ }^{1}$ Department of Invertebrate Zoology, Institute of Systematics and Evolution of Animals, Polish Academy of Sciences, Kraków, Poland

${ }^{2}$ Department of Invertebrate Evolution, Institute of Zoology and Biomedical Research, Jagiellonian University, Kraków, Poland

${ }^{3}$ Department of Life Sciences, Natural History Museum, London, UK

Corresponding Author:

Łukasz Przybyłowicz ${ }^{1}$

ul. Sławkowska 17, Kraków, 31-016, Poland

Email address: lukasz@isez.pan.krakow.pl

\section{Abstract}

Malagasy Syntomini (Polka Dot Moths) are one of the largest endemic lineages of Lepidoptera on the island, belonging to the Tiger Moth subfamily (Arctiinae). This diverse radiation comprises nearly 100 valid described species that share a single ancestor. Despite a monograph in 1964 by Paul Griveaud, systematics of the group greatly needs modern revision, and their distribution on the island is still poorly known. This contribution concerns the diversity of Syntomini of the Réserve Spéciale d'Ambohitantely, which protects the largest remaining but already highly fragmented vestige Central Plateau rainforest in Madagascar. Here we provide an annotated checklist of the eight species occurring in the Reserve. Two species are recorded from the forest for the first time, while five endemics are still now known only from Ambohitantely. We also describe for the first time the female of Thyrosticta vestigii Griveaud, 1964 and of Maculonaclia tampoketsya Griveaud, 1969, as well as a yellow morphotype of Thyrosticta dilata Griveaud, 1964, and we redescribe and illustrate the genitalia of remaining species. The significance of such colour pattern variation in aposematic moths and the role of this Reserve as a local centre of diversity of Malagasy Syntomini together with its importance in the protection of the biodiversity of Madagascar are discussed. 
38

39

40

41

42

43

44

45

46

47

48

49

50

51

52

53

54

55

56

57

58

59

60

61

62

63

64

65

66

67

68

69

70

71

72

73

74

75

76

77

\section{Introduction}

The biodiversity of Madagascar is characterised by high overall endemism rate of flora and fauna. Despite the fact that an estimated $74 \%$ of Malagasy butterfly species live solely there (Vences et al., 2009), endemism of higher taxonomic units within Lepidoptera fauna is very rare (species- and generic-level endemism predominates), and the only few higher-rank exceptions encompassing small number of species (Whalleyanidae - 2 spp., Callidulidae: Griveaudiinae -3 spp., Hesperiidae: Malazinae - 3 spp.; Drepanidae: Nidarini - 5 spp., Erebidae:

Phryganopterygina - 20 spp.) (Lees \& Minet, 2003; Zhang et al., 2020; see also Twort et al., 2020). However, the most outstanding example of Lepidoptera endemism on the island are members of the tribe Syntomini. Presently they comprise 99 valid described species in 15 genera, entirely endemic to Madagascar (Viette, 1990; with exclusion of Euchromia spp. in Arctiini, Zenker et al., 2017). Fourteen of these genera (98 spp.) belong to a single evolutionary lineage deriving from a megadiverse radiation, which also gave raise to what have been interpreted as out-of-Madagascar dispersal events, reaching Africa (Pseudonaclia puella (Boisduval, 1847)), Mauritius and even the Palaearctic (genus Dysauxes) (Przybyłowicz et al., 2019; Przybyłowicz et al., 2021, unpublished data). However, since the "Amatidae" monograph of Griveaud (1964), little attention has been paid to the systematics and biogeography of the group, with only a few additional species described by P. Griveaud and P. Viette that were listed in Viette (1990), until the phylogenetic paper of Przybytowicz et al. (2019). The latter paper and our further examinations show that the present systematic arrangement comprises several genera which are artificial assemblages of closely unrelated species rather than evolutionary monophyletic units. Thus, the diversity of Malagasy Syntomini demands wider investigation and revision to reveal real relations within the clade, and this we have undertaken.

Here we focus on Syntomini of the Réserve Spéciale d'Ambohitantely, showing that it appears to be a centre of local richness and endemism for this group, despite its small size (currently around 1300 hectares, in one large and many small fragments). The Reserve is located in the Central Highlands (usually known as the Central Plateau) of Madagascar. This Plateau covers about $40 \%$ of the area of the island, but at the same time is one of the most neglected regions in terms of conservation (Goodman \& Raherilalao 2003; Kull 2012).

A checklist of Syntomini species of the Reserve is provided for the first time, with the further remarks on each of them. Females of Thyrosticta vestigii Griveaud, 1964 and Maculonaclia tampoketsya Griveaud, 1969 are described, as well as a yellow morphotype of Thyrosticta dilata Griveaud, 1964 which was omitted in its original description. We also redescribe the genitalia of collected species and illustrate them with photographs. These species have already been described and illustrated by Griveaud $(1964 ; 1969)$, but in a very general and schematic way. This paper is the first of a series planned to adequately describe the syntomine fauna of the island. In terms of diversity, endemism and importance for biodiversity conservation and evaluation this rich radiation may be of similar importance to the lemurs (Mittermeier et al., 2010) but have been neglected in recent surveys. 


\section{Materials \& Methods}

79

80

81

82

83

84

85

86

87

88

89

90

91

92

93

94

95

96

97

98

99

100

101

102

103

104

105

106

107

108

109

110

111

112

113

114

115

116

117

\section{Abbreviations}

ISEA PAS - Institute of Systematics and Evolution of Animals Polish Academy of Sciences, Kraków, Poland

MNHN - Muséum national d'Histoire naturelle, Paris, France

NHMUK - Natural History Museum, London, United Kingdom

PBZT - Parc Botanique et Zoologique de Tsimbazaza, Antananarivo, Madagascar

DCL - David C. Lees

ŁP - Łukasz Przybyłowicz

Wing venation:

$1 \mathrm{~A}+2 \mathrm{~A}-$ anal vein

CuA1-CuA2 - cubital veins

$\mathrm{DC}$ - discal cell

M1-M3 - medial veins

R1-R5 - radial veins

\section{Study area}

Research was conducted in the Réserve Spéciale d'Ambohitantely, $80 \mathrm{~km}$ north-northwest as measured linearly (though about $130 \mathrm{~km}$ by the road) from the capital city Antananarivo (Fig. 1A). The Reserve, situated mostly between $1250-1500 \mathrm{~m}$ elevation, with the highest point at about $1670 \mathrm{~m}$, is located in the Central Highlands of Madagascar, in the eastern part of the geological/vegetational formation referred as Tampoketsa (high plateau) d'Ankazobe (Abraham et al., 1996; Goodman, Raherilalao \& Wohlhauser, 2018). Its total surface equals to 4950 ha (5600 ha in the original creation decree) (Goodman, Raherilalao \& Wohlhauser, 2018), and comprises the only significant area of forest in the Ankazobe region (Klein, 2004) and actually one of the last remnants in the Central Highlands at all (Ratsirarson et al., 2003), along with Ankazomivady (Goodman et al., 1998), today very degraded.

The most up to date map of vegetation of the area, including different types of land coverage, based on the analysis of satellite images from 2017 will be published soon by S.M. Goodman (2021, unpublished data). The map prepared by us (Fig. 1B), basing on aerial photographs from Google Earth Pro taken in 2016, is aimed to show fragmentation of woody vegetation into numerous patches, including areas covered with dense forest, as well as small groups of trees growing in ravines, which are not necessarily comparable in quality and composition to closed-canopy forest. It corresponds with the commonly cited (e.g. Langrand \& Wilmé, 1997; Vallan, 2000; 2003) map of Langrand (1995) based on the aerial photographs from 1991. Fragments of forest in the Reserve and in $10 \mathrm{~km}$ wide peripheral zone cover together a calculated 1302.4 ha and are separated by grasslands and marshy patches (Goodman, Raherilalao \& Wohlhauser, 2018; S.M. Goodman, 2021, unpublished data). 
118

119

120

121

122

123

124

125

126

127

128

129

130

131

132

133

134

135

136

137

138

139

140

141

142

143

144

145

146

147

148

149

150

151

152

153

154

155

156

157

Forest in the Reserve is not constrained to valley bottoms as in surrounding areas but covers also hilltops (Fig. 1C). It can be generally classified as medium elevation moist evergreen forest, a formation characteristic for the floristic Central Domain of Madagascar (Gautier et al., 2018), with few variants of vegetation composition identified there, depending to topography and probably corresponding with different stages of its restoration (Goodman, Raherilalao \& Wohlhauser, 2018). This type of forest is conditioned in Ambohitantely by a cool, humid tropical climate, with a high rainfall (around $1460 \mathrm{~mm}$ per year), falling mostly in the warm rainy period lasting for about half a year from October-November to March-April, and high air humidity causing frequent morning mists (Langrand, 2003; Goodman, Raherilalao \& Wohlhauser, 2018). High Plateau forests are considered relict, nonetheless grassland is also a naturally occurring vegetation type of the Central Plateau of Madagascar (Solofondranohatra et al., 2020), but nowadays disrupted. In Ambohitantely secondary grasslands cover $40 \%$ of the protected area (Ratsirarson et al., 2003; Goodman, Raherilalao \& Wohlhauser, 2018). The ecotone between forest and grassland is most often sharp (Vallan, 2000), but relatively narrow intermediate zones of secondary shrubby vegetation are also present in some parts of the Reserve (Fig. 1D). Human impact on the environment of the Central Plateau is undeniable (Langrand 2003; Goodman, Raherilalao \& Wohlhauser, 2018), however its extent has been a subject of a great debate, reaching back to the 19th century (Klein, 2004; see also discussion).

\section{Sampling methods and morphological studies}

Field collecting was undertaken under the permits Nos. 251/06/MINENV.EF/SG/DGEF/DPB/SCBLF/RECH and 292/19/MEDD/SG/DGEF/DGRNE from Direction Generale de l'Environment et des Forets and Direction de la Gestion des Ressources Naturelles Renouvelables et des Ecosystemes. Material was collected during three visits: 6-7 December 2006, 11-12 December 2019 and 13-16 March 2020, in the southern part of the Reserve ( $\mathrm{S} 18.1969^{\circ}, \mathrm{E} 47.2847^{\circ}$ ), close to the camp located near the largest patch of forest (S 18.1981 ${ }^{\circ}, \mathrm{E} 47.2816^{\circ}$ ). Moths were sampled at night with the use of automatic light traps with UV-A (blacklight) or a $6 \mathrm{~W}$ white fluorescent light source, or at a three spectral peak LEPI-LED (Brehm, 2017) inside a reflective screen column, and during the day, between 10 am and 5 pm, by walking slowly through the forest paths and looking for individuals sitting on the upper side of leaves and catching them with a standard entomological net, what is the most efficient method of collecting Malagasy Syntomini (Przybyłowicz et al., 2021, unpublished data). Day collecting was conducted within a distance of few hours of slow walk from the camp, the final point marked at a cascade equivalent to near the centre of the largest patch of the forest (Fig. 1B). The light traps were set at dusk (about $6 \mathrm{pm}$ ) and left overnight in proximity of the camp site in different habitats: inside the dense forest, as well as among shrubby vegetation on its edges and on sparse trees in grassland surrounding the forest, ca. $100 \mathrm{~m}$ from the forest edge (Fig. 1B). In the latter case the light trap was clearly visible for potential moths flying out from the forest. Collected moths were killed with ethyl acetate and pinned on standard entomological pins. Individuals were spread after legs were sampled for molecular studies and photographed with a 
158 Canon 70D camera before the further examination. The images were adjusted with Adobe

159

160

161

162

163

164

165

166

167

168

169

170

171

172

173

174

175

176

177

178

179

180

181

182

183

184

185

186

187

188

189

190

191

192

193

194

195

196

197

Photoshop. Specimens are deposited in the collection of ISEA PAS, Kraków, Poland, accession numbers of the specimens are provided in Supplemental Table S1.

Genitalia were dissected from one specimen of each sex of collected species, except for males of Tsarafidynia perpusilla, where two slides of the same sex were prepared. Abdomens were macerated in $10 \% \mathrm{KOH}$ in water bath, then obtained genitalia were stained with chlorazol black, embedded in Euparal (Essex, U.K.) and mounted on slides. Photographs of the genitalia were taken with the use of a stereoscope microscope Leica S9i system. Images were adjusted with the Adobe Photoshop Programme.

The general morphological terminology follows Miller (1991), and for genitalia we refer to Koda (1987). Measurement of forewing length (in $\mathrm{mm}$ ) was taken with the use of a digital caliper.

We summarise our results with updated data published on distribution and ecology of Syntomini species occurring in the Réserve Spéciale d'Ambohitantely. Official names of protected areas mentioned in the text follow Goodman, Raherilalao \& Wohlhauser (2018). The most important collections of Malagasy Syntomini, including type specimens of majority of the species, are deposited in three institutions: MNHN in Paris, NHMUK in London and PBZT in Antananarivo. However, we may have missed some information, as in the latter collection, red paratype labels are pinned under the main labels, thus in available photographs were visible partially, if at all. Moreover, some species have more specimens labelled as paratype than designated in Griveaud (1964), even taking into consideration only London and Paris collections, where the photographed labels are clearly visible. These last collections were inaccessible for examination at the time of writing (due to COVID-19). Thus, to make some morphological and taxonomical remarks and to confirm localisation of type specimens of species that are dealt with in the paper, we relied on photographs of specimens and genital slides taken by ŁP in MNHN in 2015 and in PBZT in 2019. Detailed photographs of type specimens and their labels from NHMUK are available on AfroMoths (De Prins \& De Prins, 2011-2019) and from MNHN are available in the Museum online database of the Lepidoptera collection (https://science.mnhn.fr/institution/mnhn/collection/el/item/search).

\section{Molecular studies}

For molecular investigation, two legs from each specimen were sampled. Isolation of genomic DNA was done with the NucleoSpin Tissue kit (Machery-Nagel, Germany), following the manufacturer's protocol. Sequences of the first part of the mitochondrial gene cytochrome $\mathrm{c}$ oxidase subunit I (COI) were obtained with the use of $\mathrm{HCO} / \mathrm{LCO}$ primers pair hybridised with the universal primer pair T7/T3, described by Wahlberg \& Wheat (2008). PCR was done with the use of hot-start ready PCR mix (StartWarm HS-PCR Mix, A\&A Biotechnology, Poland), protocol followed manufacturer's instructions. Obtained sequences were compared with chromatograms, aligned manually with a template sequence in BioEdit software (Hall, 1999). Ambiguous sites were coded in accordance to the IUPAC nucleotide code.

Peer) reviewing PDF | (2021:03:59387:1:1:NEW 27 May 2021) 
198

199

200

201

202

203

204

205

206

207

208

209

210

211

212

213

214

215

216

217

218

219

220

221

222

223

224

225

226

227

228

229

230

231

232

233

234

235

236

237

Prepared sequence files were managed with VoSeq database (Peña \& Malm, 2012). Sequences were analysed in a Maximum Likelihood framework in IQ-TREE (Nguyen et al., 2015) on the web server (Trifinopoulos et al., 2016) with 1000 replications of Ultrafast Bootstrap (Minh, Nguyen \& von Haesler, 2013). The p-distance between barcode sequences was calculated in MEGA X (Kumar et al., 2018). The outgroup sequence of Fletcherinia decaryi Griveaud, 1964 (GenBank accession code MK158546) was obtained from the study of Przybytowicz et al. (2019). DNA sequences are deposited in GenBank (MW817635-MW817665), accession codes are provided in Table $\mathrm{S} 2$.

\section{Results}

\section{Checklist of Syntomini of Réserve Spéciale d'Ambohitantely and general remarks} During three expeditions to Ambohitantely 58 specimens of Syntomini belonging to seven species of four genera were collected. In total, the fauna of Syntomini of the Reserve comprises eight species, of which two are recorded for the first time (marked with '!'). At the current stage of knowledge on distribution of Malagasy Syntomini, five species appear to occur only in this area (marked with ‘*'):

\section{*Maculonaclia altitudina Griveaud, 1964}

!Maculonaclia ankasoka Griveaud, 1964

*Maculonaclia brevipenis Griveaud, 1964

*Maculonaclia tampoketsya Griveaud, 1969

*Thyrosticta dilata Griveaud, 1964

*Thyrosticta vestigii Griveaud, 1964

Tritonaclia stephania (Oberthür, 1923)

!Tsarafidynia perpusilla (Mabille, [1880])

Three species: Maculonaclia ankasoka, Tritonaclia stephania and Tsarafidynia perpusilla are known from several localities in central, eastern and southern parts of Madagascar (Fig. 2). Most of them are located near or within protected areas, what is indicated in the text. In all these areas, as well as in Ambohitantely, dominating type of vegetation is medium elevation moist evergreen forest (sensu Gautier et al., 2018). These above three more widely distributed species mentioned above occur between 800 and 1600 m elevation, with Ambohitantely being the highest observed locality in all the cases.

Type specimens of the most of Malagasy Syntomini species, including all described by $\mathrm{P}$. Griveaud, are deposited in three collections, but in Griveaud (1964) only details concerning holotypes and allotypes were given. Generally, holotypes as well as part of paratypes are housed in MNHN Paris, remaining paratypes are in NHMUK London and in PBZT Antananarivo. 
238 Specimen data, descriptions and remarks on the species

239

240

241

242

243

244

245

246

247

248

249

250

251

252

253

254

255

256

257

258

259

260

261

262

263

264

265

266

267

268

269

270

271

272

273

274

275

276

277

\section{Maculonaclia altitudina Griveaud, 1964}

\section{Distribution}

Until now recorded only in the Réserve Spéciale d'Ambohitantely.

\section{Remarks}

Maculonaclia altitudina is the only Syntomini species occurring in the Reserve, which was not collected during our study. This species is known only from type series, consisting of the male holotype and seven paratypes, all collected in the Reserve by A. Robinson in May 1961 at an elevation of $1550 \mathrm{~m}$. The female remains unknown (Griveaud, 1964). Holotype and three paratypes are deposited in MNHN, one paratype is in NHMUK. Further three specimens are in PBZT, and their collecting data labels are identical to these of specimen in Paris and London, thus they probably are remaining paratypes. Among specimens labelled as paratype of Maculonaclia altitudina in Paris there is one additional specimen, undoubtedly belonging to the species Maculonaclia brevipenis, that is similar in general appearance, but distinctly differs in details of forewing pattern. As discussed below, the type series of Maculonaclia brevipenis in Paris contains many more specimens labelled as paratypes than stated by Griveaud (1964), and all the specimens of both species were collected in the same place, at the same time and by the same collector.

All the known specimens of Maculonaclia altitudina were collected in May, in the cool dry period.

\section{Maculonaclia ankasoka Griveaud, 1964 (Figs 2A, 3A, 4A)}

Material (1 specimen). 1요 8.xii.2006, Ankazobe District, Ambohitantely Reserve (1600 m), lgt. Ravo Ranaivosolo.

Distribution (Fig. 2A)

The species is recorded for the first time from the Ambohitantely Reserve. Until now it has been known from four localities given by Griveaud (1964) (from north to south): Périnet [=Andasibe], Ankasoka and Sandrangato - all three located close to each other in the area of the southern parts of the Réserve de Ressources Naturelles du Corridor Ankeniheny-Zahamena and Parc National d'Analamazoatra (on the map all three marked as one point); Tsarafidy - few kilometres W from Parc National de Ranomafana and about $32 \mathrm{~km}$ NNE of Fianarantsoa. Occurs between 900 and $1600 \mathrm{~m}$ elevation. Ambohitantely is so far the northernmost locality.

\section{Redescription of female genitalia (Fig. 4A)}

Papillae anales subtriangular with rounded protrusion at base of dorsal margin, covered with short erected setae, much denser on the protrusion; dorsal and ventral pheromone glands present in form of very narrow, elongate, not anastomosing membranous tubes; apophyses posteriores almost as long as papillae anales, straight and narrow, needle-like; apophyses anteriores of 
278 similar shape and size as apophyses posteriores; ostium bursae rounded; antrum well developed, 279 sclerotised, cylindrical, slightly longer than wide; ductus bursae membranous, slightly widening 280 towards corpus bursae, terminal portion with sublateral diverticulum directed distally, from

281 which narrow, membranous ductus seminalis originates;

282 corpus bursae forming a membranous, oval pouch bearing indistinct, irregular zones of minute, 283 diffuse scrobinations; central portion with a pair of signa in form of short, parallel ridges

284 consisted of tiny subtriangular sclerotised plates, leaning on each other; along a longitudinal axis 285 designated by the signa, scrobinations are slightly strongly articulated.

\section{Remarks}

287 Male and female genitalia were described and illustrated by Griveaud (1964: Figs 87-90).

288

289

290

291

292

293

294

295

296

297

298

299

300

301

302

303

304

305

306

307

308

309

310

311

312

313

314

315

316

317

318

Corpus bursae is depicted to possess scrobinations only in the rhomboidal areas surrounding each of two signa. In the genital slide of allotype (MNHN) these areas are indeed more prominent than in the slide prepared from our specimen (Fig. 4A), where minute scrobinations are diffuse over whole corpus bursae, and only slightly larger around signa. It could be a matter of intraspecific variation, but also an effect of different staining technique, as slides of Griveaud are prepared with eosin, whereas our ones with chlorazol black. This issue needs further examination in the future on larger series of specimens.

Type series of Maculonaclia ankasoka designated by Griveaud (1964) is given to comprise 10 specimens: male holotype, and nine paratypes (one male and eight females of which one labelled as allotype). The holotype and the male paratype were collected by P. Griveaud in November 1956 in Ankasoka at an elevation of 1000 m (however original label of the holotype says " $1130 \mathrm{~m}$ "), the allotype and the remaining female paratypes in February 1961 at Périnet, elevation $900 \mathrm{~m}$ (Griveaud, 1964). The holotype, allotype and three other paratypes are deposited in MNHN. In Paris are also other seven specimens: four collected by P. Griveaud and R. Vieu in 1956 and three collected in 1959, 1963 and 1964 by P. Viette (detailed collecting data illegible in the photographs). A further about 30 specimens determined as Maculonaclia ankasoka are in the PBZT collection, collected mostly by P. Griveaud. Three of them are most probably remaining paratypes, as their labels agree with data given by Griveaud (1964).

\section{Maculonaclia brevipenis Griveaud, 1964 (Figs. 3B, 5A)}

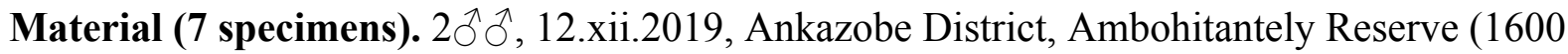
$\mathrm{m}$ ), S $18.1969^{\circ}, \mathrm{E} 47.2847^{\circ}$, lgt. $Ł P ; 5 \overbrace{}^{\Uparrow}$ as above but $14-15$. iii.2020 (all collected by netting at day).

\section{Distribution}

Until now recorded only in the Réserve Spéciale d'Ambohitantely.

\section{Redescription of male genitalia (Fig. 5A)}

Tegumen narrow, moderately sclerotised, almost completely fused with vinculum; uncus elongate, dorso-ventrally flattened, slightly concaved in ventral surface; of the same width up to sharply narrowed, ventrally incurved hook-like tip; dorsally covered with erected setae, longer in basal portion; vinculum narrow produced with a prominent saccus of triangular shape; juxta well

Peer) reviewing PDF | (2021:03:59387:1:1:NEW 27 May 2021) 
319 developed, divided into transverse ventral plate and a pair of lateral, rectangular plates; valva

320

321

322

323

324

325

326

327

328

329

330

331

332

333

334

335

336

337

338

339

340

341

342

343

344

345

346

347

348

349

350

351

352

353

354

355

356

357

358

approximately the length of uncus with terminal half of triangular shape; costa evenly convex, widely folded towards inner zone; tiny, tooth-like protrusion in the $1 / 3$ of folded costal margin; saccular margin shallowly sinusoidal; margins and some regions of internal and external surface with short erected setae; aedeagus weakly sclerotised, short, tubular, slightly narrowing towards apex; vesica membranous, bag-like, with four small sclerotised plates of irregular shape in latero-distal portion.

\section{Remarks}

Male genitalia were described and illustrated by Griveaud (1964: Figs 95-97). Figures show valva with sharply terminated apex, narrow elongate saccus, and vesica was uneverted. In fact the valva is dully terminated and saccus is triangular, but not elongate, vesica as described above.

Until now the species has been known from the type series, according to Griveaud (1964) consisting of the male holotype and two paratypes, collected by A. Robinson in May 1961 at an elevation of $1550 \mathrm{~m}$. The female remains unknown. However, in MNHN, except the holotype, are deposited 10 specimens marked as paratypes, labelled with identical collecting data as given above. Further two paratypes are deposited in NHMUK. Another 13 specimens with identical labels are in PBZT collection, at least one of which is also labelled as a paratype, because a fragment of a red label is visible from under the collecting data label.

All the known specimens were collected in December, March and May, during the warm rainy period and at the beginning of the cool dry period.

\section{Maculonaclia tampoketsya Griveaud, 1969 (Figs 3C, 4B, 5B, 6)}

Material (2 specimens). 10, 11-12.xii.2019, Ankazobe District, Ambohitantely Reserve (1600 $\mathrm{m}), \mathrm{S} 18.1969^{\circ}$, E $47.2847^{\circ}$, lgt. $Ł P ; 19$ as above (all attracted by light).

\section{Distribution}

Until now recorded only in the Réserve Spéciale d'Ambohitantely.

\section{Redescription of male genitalia (Fig. 5B)}

Tegumen completely fused with vinculum, very narrow, moderately sclerotised, with a pair of prominent, sharp, claw-like protrusions directed ventrally, close to the uncus base; uncus large, elongated, bent ventrally, laterally flattened, with tiny spike-like protrusion at the tip; basal half with numerous long setae; saccus short, terminated with tiny, narrow protrusion; valva elongate, reaching almost to uncus tip, narrowed terminally into sclerotised, hook-like process slightly curved ventrally; costal margin widely sclerotised, concaved submedially, with some undulation in its basal portion; concavity marked with a narrow, membranous, joint-like articulation; sacculus sclerotised, reaching till $2 / 3$ of valva length, with short erected setae, extending beyond; a short spike-like protrusion at dorsoterminal margin beyond sacculus; central inner portion of valva membranous; aedeagus tubular, widened subbasally, slightly bent dorsally in distal portion; vesica in form of membranous tube evenly widened in proximal $2 / 3$ of its length, bearing a dense bunch of elongate, needle-like cornuti in terminal portion. 
359

360

361

362

363

364

365

366

367

368

369

370

371

372

373

374

375

376

377

378

379

380

381

382

383

384

385

386

387

388

389

390

391

392

393

394

395

396

397

398

399

Remark: The short spike-like protrusion at dorsoterminal margin beyond sacculus visible only on right valva. Left valva with indistinct convexity.

\section{Description of female (Fig. 3C)}

Head. Proboscis well developed, brown, apex and base pale brown; frons pale yellow, with longitudinal ochraceous stripe from clypeal portion towards second third; vertex ochraceous with admixture of pale yellow scales, lateral margins yellow, ochraceous stripe between scapi; palpi three-segmented, porrect, yellow, ventrally with elongate scales, dorsally with admixture of ochraceous scales, terminal palpomere dorsally entirely ochraceous; antennae filiform, ochraceous with admixture of creamy scales, except terminal, dark ochraceous quarter.

Thorax. Patagia of piliform scales, submedially ochraceous with tiny yellow spot in central portion, laterally pale yellow; tegulae pale yellow with elongate scales almost piliform in distal portion, terminally with admixture of ochraceous; subventral zone ochraceous; mesothorax ochraceous, medially with longitudinal narrow yellow stripe and yellow spot in distalomedian portion; metathorax ochraceous; ventral portion of pleurites ochraceous, with yellow blotches at base of coxa; foreleg: pale yellow, epiphysis absent; midleg: pale yellow, tibia with one pair of terminal spurs of similar length; hindleg: coxa and femur pale yellow; remaining parts of the hindleg unavailable.

Abdomen. Ochraceous, distal margin of each segment with yellow stripe.

Forewing. Length of costa $11 \mathrm{~mm}(\mathrm{n}=1)$; upperside background ochraceous, with short, yellow, narrow streak along proximal portion of dorsum and additional 5 pale yellow to creamy blotches of subrectangular shape and similar size: 1 at basal 2 at medial and 2 at distal portion of wing; basal one elongate, from costal margin to the half of the wing width, with a prominent narrow projection towards wing base on $\mathrm{R}$ vein; first medial one of rectangular shape, form costal margin to hind margin of DC; second medial one of irregular shape, from cubital vein, widening towards termination before inner margin; first distal one elongate, from costal margin to M3, constricted in medial portion along M1; second distal one below $\mathrm{CuA} 1$, of irregular shape, separated from outer margin by narrow ochraceous stripe; underside with the same pattern, with addition of zone of scattered pale yellow scales between the basal blotch and $1 \mathrm{~A}+2 \mathrm{~A}$; cilia ochraceous.

Hindwing. Elongate, reaching about half of forewing; basal portion yellow, reaching to the basalodistal angle and to $3 / 4$ of the length of costal margin, with large, 8 -shaped elongate ochraceous blotch, originating from the wing base and including most of DC, but not reaching to its outer margin nor the costal margin of the wing; outer area ochraceous; underside pattern the same but lateral portion of brown blotch reaches the costal margin; piliform scales along wing margins, longer on basalodistal margin; frenulum present.

\section{Female genitalia (Fig. 4B)}

Papillae anales semicircular, covered with short, dense, erected setae; dorsal pheromone glands present in form of narrow, rather stright, not anastomosing tubes, of about three lengths of apophyses posteriores; apophyses posteriores strongly sclerotised, straight and narrow, needlelike; apophyses anteriores in form of subtriangular, short lobes, half of the length of apophyses posteriores; 7th and 8th segments heavily sclerotised; 7th sternite wide and narrow with 
400 shallowly concave distalomedian margin and a pair of shallow depressions at anterolateral 401 corners; 8th sternite with distinct, expanded, subtriangular wrinkled cavities at anterolateral 402 margin; posterior margin in form of prominent, sclerotised ridge provided medially with deep, 403 U-shaped slit connected with ostium bursae by well-defined concavity of parallel margins; 404 ostium bursae rounded, strongly sclerotised; antrum well developed, strongly sclerotised, 405 distinctly bent distally to the left (according to body axis); ductus bursae strongly bent to the 406 right towards the medial axis, membranous, of length of antrum, slightly widened terminally, 407 with plicae in form of longitudinal parallel ridges; ductus seminalis from anterior portion of 408 antrum just below the ostium; corpus bursae membranous, pear-shaped, bearing extensive, 409 irregular zone of minute, diffuse scrobinations; central portion of which with a pair of spiny 410 signa, proximal one elongate, terminal one rounded with longer spines than in proximal one.

\section{Remarks}

412 We collected one specimen of each sex, thus in that case we were allowed to confirm that they 413 are conspecific not only by morphological, but also molecular examination (Fig. 6). The genetic 414 distance between barcode sequences (p-distance), equals to 0.00 (Table S2).

Male was illustrated as linear drawing by Griveaud (1969: pl. I, Fig. B), but in the figure caption referred as "Melanonaclia tampoketsya", what is certainly an unintended error, as in the description this species is explicitly attributed to the genus Maculonaclia and section of Maculonaclia ankasoka established within the genus by Griveaud (1964). Male genitalia were

420

421

422

423

424

425

426

427

428

429

430

431

432

433

434

435

436

437

438

439 described and illustrated in the same paper (Griveaud, 1969: Figs 9-12), but with uneverted vesica of aedeagus, which is described above.

Up to now the species has been known only from male holotype collected by P. Griveaud in April 1967, deposited in MNHN (Griveaud, 1969). In male general body colouration and pattern are similar as in female, with differences listed below: eyes are much larger, with tuft of yellow scales at the eye margin, below scapus; frons is narrower; vertex is uniformly ochraceous, with yellow lateral margins and small yellow spot in central part, over axis between scapi; antennae are serrate, shaft dorsally golden-yellowish, each pectine with golden-yellowish lobe directed downwards, cowered with short, dense, erected setae; hindleg tibia possess one pair of spurs of slightly uneven length; all legs have well-developed arolium; retinaculum is present. Male palpi are similar as in female, i.e. yellow, dorsally with admixture of ochraceous scales, terminal palpomere dorsally entirely ochraceous, but in original description (Griveaud, 1969) are referred as entirely ochraceous, what can be intraspecific variation and needs to be revised in MNHN collection.

All the known specimens were collected in April and December, thus both in cool dry and warm rainy period. 
440

441

442

443

444

445

446

447

448

449

450

451

452

453

454

455

456

457

458

459

460

461

462

463

464

465

466

467

468

469

470

471

472

473

474

475

476

477

478

479

Thyrosticta dilata Griveaud, 1964 (Figs 3E-F, 5D-E, 6)

\section{Black morphotype}

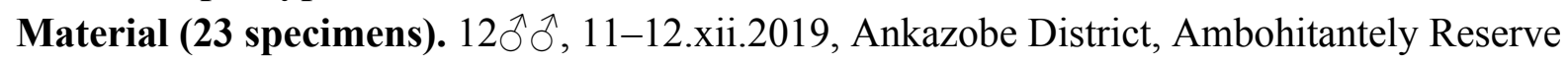

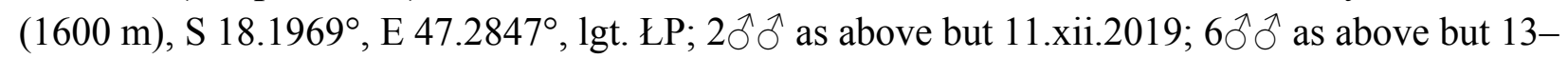
15.iii.2020 (all above attracted at light); $2 \hat{\jmath} \widehat{\jmath}$ as above but 14-15.iii.2020; $1 \hat{\sigma}$ as above but 12.xii.2019 (latter 3 collected by netting at day).

\section{Yellow morphotype}

Material (22 specimens). 15 $\hat{\jmath}, 11-12 . x i i .2019$, Ankazobe District, Ambohitantely Reserve $\left(1600 \mathrm{~m}\right.$ ), S $18.1969^{\circ}, \mathrm{E} 47.2847^{\circ}$, lgt. ŁP; 5 ふ઼ as above but 13-15.iii.2020 (all above attracted at light); $1 \hat{\delta}$ as above but 12.xii.2019; $1 \delta^{\lambda}$ as above but 14-15.iii.2020 (latter 2 collected by netting at day).

\section{Distribution}

Until now recorded only in the Réserve Spéciale d'Ambohitantely.

\section{Taxonomic status}

This species is represented by two morphotypes, described in detail below. Despite variation within and clear differences between them, our morphological and molecular results confirm that they belong to the same species. There is no difference in male genitalia (Fig. 5D-E), also pdistance between barcode sequences of specimens has values from $0-0.2 \%$ with no regard to morphotypes (Table S2), and all the specimens represent a single clade on the tree (Fig. 6).

\section{Description of the yellow form (Fig. 3F)}

Head. Proboscis well developed, black, with ochraceous-yellowish apex; frons yellow, few pale ochraceous scales close to eye margin; vertex yellow, with black stripe between scapi and ochraceous longitudinal spot in median part; palpi porrect, terminally curved downward; palpomeres of comparable length, elongated, at least three times longer than wider; first two palpomeres yellow, with ochraceous scales on dorsal part; first with piliform scales on ventral part; third palpomere ochraceous, with admixture of yellow scales; antennae bipectinate; Scapus yellow ventrally, ochraceous dorsally; shaft black ventrally, dorsally yellow at base, distally from base with admixture of ochraceous scales, increasing towards entirely ochraceous apex; pectines black with numerous dense, short, erected setae; on each pectine 3 yellowishochraceous setae of uneven length, apical one the longest and most visible.

Thorax. Patagia black with admixture of ochraceous and yellow scales in lateral parts; tegulae yellow, black basally; mesothorax yellow with dark ochraceous central portion; metathorax with elongated scales, medially yellow, laterally ochraceous; ventral pleurites yellowish-ochraceous with yellow spots at base of mid and hind coxa; foreleg: coxa ochraceous with pale yellow stripe on lateral and distal margins; femur and tibia ochraceous medially, yellow laterally; epiphysis ochraceous, reaching 3/4 the length of tibia; tarsus ochraceous, segments 1-3 partially pale yellow; midleg: coxa pale ochraceous; femur yellow, ochraceous terminally; tibia pale ochraceous medially, pale yellow laterally, one pair of pale yellow terminal spurs of uneven length; tarsus pale yellow with pale ochraceous admixture; hindleg: coxa pale ochraceous; femur 
480 pale yellow with pale ochraceous terminal portion; tibia pale yellow with pale ochraceous

481 admixture, two pairs of pale yellow spurs; tarsus pale ochraceous with pale yellow admixture.

482 Abdomen. Ochraceous, each segment with yellow, differently expressed distal margin, gradually

483 broadened towards the abdomen termination, hardly visible on the first tergite.

484 Forewing. Upperside background ochraceous, with narrow, yellow streak from wing base to its

485 half between costal margin and Sc, and additional four yellow blotches of different shape: two at 486 medial and two at distal portion of wing; the largest first medial blotch in DC, U-shaped, fusing

487 with the yellow streak; second rounded, between $\mathrm{CuA} 2$ and $1 \mathrm{~A}+2 \mathrm{~A}$; third one in apical region, 488 round, with comma-shape projection towards first medial one; fourth one 8-shape, between M2 489 and $\mathrm{CuA} 1$; underside with the same pattern; inner margin with piliform scales; cilia ochraceous; 490 retinaculum present.

491 Hindwing. Elongate, reaching beyond half of forewing; basal portion including DC, half of the 492 costal margin and basal portion of hind margin - yellow, and in central part forming a round 493 projection into outer ochraceous zone; underside pattern the same, with ochraceous costal 494 margin, broadened at wing base, and tiny protrusion from the margin towards central part of 495 yellow zone; hind and outer margins with elongated scales, piliform at the wing base; frenulum 496 present.

497 Redescription of male genitalia (Fig. 5D-E)

498 Tegumen moderately sclerotised, widened in dorsal portion, laterally narrowed, almost 499 completely fused with vinculum; uncus narrow, elongate, dorsally with long, erected setae; 500 slightly constricted in distal third, terminated in form of a sclerotised, sharp, dorso-ventrally 501 flattened tip; vinculum very narrow, U-shaped, without produced sacculus; valva moderately 502 elongated, subtriangular, narrowed till dull apex; terminal half including margins with short, 503 erected setae, inner portion with shallow, longitudinal convexity; costal margin of sinusoidal 504 shape, terminally with spike-like inwards curved protrusion, outer margin shallowly concave in 505 distal portion; saccus not developed; aedeagus moderately elongate, of approximately equal 506 width, L-shaped; vesica membranous, elongate, tubular; short subbasal portion distinctly bent 507 parallel to aedeagus base; its left lateral zone with pocket-like diverticulum provided with a 508 indistinct field of minute scrobinations, opposite membranous wall without diverticulum but with 509 more extensive field of distinctly thicker scrobinations; remaining portion of vesica delicately 510 spiral, provided with a belt-like longitudinal zone of granular sclerotisations covering less than a 511 half of the vesical membrane circumberence.

\section{Remarks}

513 The specimens representing yellow morphotype strongly resemble Thyrosticta vieui Griveaud, 514 1964, especially in the black-yellow striped abdomen and the general pattern of the forewing. 515 The main differences are: (i) shape of the basal blotch of the forewing, in Thyrosticta dilata 516 forming a narrow, yellow streak between costal margin and Sc, while in Thyrosticta vieui present 517 as a wider, irregular, suboval blotch with fuzzy margins, close to the costal margin; (ii) shape of 518 the projection of yellow blotch of the hindwing, distinctly narrower in Thyrosticta vieui than in 519 Thyrosticta dilata. 
520

521

522

523

524

525

526

527

528

529

530

531

532

533

534

535

536

537

538

539

540

541

542

543

544

545

546

547

548

549

550

551

552

553

554

555

556

557

558

559

The black morphotype distinctly differs from the yellow one in the characters listed below (Fig. 3E-F): head (including palpi and antennae) and thorax (including patagia) are entirely black, tegulae yellow with piliform scales. Legs are fully dark ochraceous, including spurs. Forewing has the same shape and pattern as in yellow form, but elongate streak along costal margin is always absent. Abdomen is entirely black dorsally and ventrally, first tergite possess elongated black scales.

As already mentioned, no intermediate form of Thyrosticta dilata has been detected, however both morphotypes exhibit internal variation in the colouration described below.

In the yellow morphotype $(n=22)$ ochraceous scales on frons, close to eyes margin, are absent in some specimens. The ochraceous stripe on vertex varies from a very narrow band to a globular blotch, reaching or not to the black stripe between antennae. Elongate streak on costal margin of fore wing reaches half of the wing and fuses with the second U-shape blotch or terminates before. In some specimens also comma-shape projection of apical blotch reaches close to or fuses with DC blotch, up to fuse of these three blotches, creating a yellow stripe along costal margin fused with them. When the wings pattern is strongly developed, U-shaped (the largest) and round (the second) blotches nearly touch each other, but never fuse.

In the black morphotype $(n=23)$ some specimens have general body colouration in dark ochraceous rather than blackish. In some specimens with strongly developed wings pattern Ushaped (the largest) and round (second) blotches nearly touch each other, up to fuse.

The species has until now been known only from the type series designated by Griveaud (1964), declared to consist of the male holotype and four paratypes. The female remains unknown. The holotype was collected by P. Griveaud on 27.xii.1956 at an elevation of $1600 \mathrm{~m}$. Paratypes are said to have been collected in May 1961 and to have the same provenance and collector as the holotype (Griveaud, 1964), but according to their labels, all the five specimens from May 1961 were collected by A. Robinson at an elevation of $1550 \mathrm{~m}$, not by P. Griveaud at $1600 \mathrm{~m}$.

The holotype and one paratype are deposited in MNHN, another paratype is in NHMUK. A further three specimens with labels identical as these of the paratypes in Paris and London are in PBZT, thus most probably among them are remaining two paratypes. In PBZT there are also additional four specimens, collected in April 1967 by P. Griveaud (two specimens), in October 1974 by A. Peyrieras (one specimen) and in 1970s (one specimen, exact year and name of collector illegible in the photograph). All of them were collected in the area of Tampoketsa d'Ankazobe as well, however the specimen from 1974 remains uncertain because of illegible locality on the label, except "central Madagascar".

For the reason given below, we assume that Griveaud was aware of the intraspecific variation when describing the species, but for some reason omitted it. The original description and colour illustration (Griveaud, 1964: pl. I, Fig. 60) refer to the black morphotype. However, the holotype deposited in MNHN represents the yellow morphotype, while the paratype in the same collection belongs to the black one. Genitalia were described and illustrated in Griveaud (1964: Figs 224-226), but with an uneverted vesica on the aedeagus, which is described above.

Peer) reviewing PDF | (2021:03:59387:1:1:NEW 27 May 2021) 
560

561

562

563

564

565

566

567

568

569

570

571

572

573

574

575

576

577

578

579

580

581

582

583

584

585

586

587

588

589

590

591

592

593

594

595

596

597

598

599

As indicated in the Materials section, almost all of the fresh specimens of Thyrosticta dilata were collected at light traps with both UV or non-UV white light sources, which allowed us to obtain series of well-preserved specimens. According to our observations, this is rather exceptional among Malagasy Syntomini, although DCL has observed it for some members of genera Thyrosticta and Tritonaclia at other sites. As a general rule, syntomines are attracted to light rather rarely and usually just in small numbers, which makes day netting the most efficient collecting method for the vast majority of taxa.

\section{Thyrosticta vestigii Griveaud, 1964 (Figs 3D, 4C)}

Material (1 specimen). 19 , 12.xii.2019, Ankazobe District, Ambohitantely Reserve (1600 m a.s.1.), S $18.1969^{\circ}, \mathrm{E} 47.2847^{\circ}$, lgt. ŁP (collected by netting at day).

\section{Distribution}

Until now recorded only in the Réserve Spéciale d'Ambohitantely.

Description of female (Fig. 3D)

Head. Entirely blackish ochraceous, including palpi and antennae; palpi projected downward; proboscis well developed; antennae filiform, flagellum with numerous short, erected setae.

Thorax. Concolorous with head both dorsally and ventrally, including patagia and filiform tegulae; metascutellum with partially filiform scales; legs entirely blackish ochraceous, with exception of paler epiphysis on foreleg; mid and foreleg tibia with one pair of terminal spurs. Abdomen. Entirely blackish ochraceous dorsally and ventrally, with admixture of piliform scales.

Forewing. Length of costa $7 \mathrm{~mm}(\mathrm{n}=1)$; upperside blackish ochraceous, with two partially fused yellow blotches; first one prominent, reaching from the wing base up to half of the wing length terminating at DC outer margin; costal portion along R stem with indistinct, shallow, concavity in its half-length; opposite margin in proximal part along narrow ochraceous streak of inner margin of wing, in distal part directed to a right-angle-shape blotch termination; second blotch in postdiscal zone, of dumbbell-shape, fusing narrowly in inner posterior angle with the tip of first blotch; cilia and scales along inner margin elongate concolorous with background; underside pattern the same.

Hindwing. Oval, elongated, reaching beyond the half of fore wing; basal part including DC with yellow oval zone, reaching to the basalodistal angle and beyond the half of the costal margin; outer zone brown, with narrow brown margin along costa; underside pattern the same, with addition of short brown protrusion from brown costal margin towards central part of yellow zone; elongated scales on outer and hind margins, with dominance of piliform scales close to wing base; frenulum present.

\section{Female genitalia (Fig. 4C)}

Papillae anales subtriangular, covered with erected setae, much denser and longer in ventral portion; dorsal pheromone glands well developed, in form of four very narrow, elongate, twisted, rarely anastomosing membranous tubes; two sublateral much longer than two submedial; 
600 apophyses straight and narrow, needle-like; posteriores as long as papillae anales, anteriores 601 slightly shorter; ostium bursae membranous, with lateral projections of subtriangular shape, 602 covered with minute scrobinatios; antrum well developed, wide and at least two times longer 603 than wide, plain, weakly sclerotised; proximal margin of 7 th segment laterally with symmetrical 604 pocket-like cavities covered with scales; ductus bursae membranous, constricted in middle 605 portion, inner wall in form of sclerotised plate, outer one membranous with well defined, 606 longitudinal, parallel plicae; corpus bursae in form of membranous, elongate pouch, entirely 607 covered with remarkable plicae in form of longitudinal, parallel ridges; signum singular, 608 prominent, forming a strongly sclerotised, narrow, elongate longitudinal buckle, located at 609 laterobasal portion of corpus bursae; initial portion of signum widened and folded inwards, palm610 shaped, formed of four subtriangular plates of different size; terminal portion straight, reaching 611 half of corpus bursae, with longitudinal row of spine-like protrusions of different length directed 612 inwards corpus bursae, and row of few scrobinations on outer surface; below the signum, in

613 terminal third of corpus bursae three tiny spine-like scrobinations directed inwards; ductus

614 seminalis narrow, from membranous diverticulum in basal portion of corpus bursae.

615 Remarks

616 Body colouration and wing pattern of female is generally the same as in male. All the blackish617 ochraceous body parts have golden-yellowish reflections.

618 The male and its genitalia were described and illustrated in Griveaud (1964: Pl. I, Fig. 56; Figs. 619 208-210).

620 Until now the species has been known only from male holotype and two paratypes 621 collected by A. Robinson in May 1961 at an elevation of $1550 \mathrm{~m}$ (Griveaud, 1964). The holotype 622 and one paratype are deposited in MNHN. One specimen has an identical label, thus being most 623 probably the second paratype is in PBZT. In the latter collection there is also one additional worn 624 specimen, labelled as collected in "Tampoketsa d'Ankazobe" in October 1974 by A. Peyrieras. 625 Thus, this specimen was collected somewhere around the Ambohitantely Reserve, and the 626 species remains endemic to the area.

627 All the specimens known to us were collected in October, December and May, so both 628 during the warm rainy period and at the beginning of the cool dry period.

629

630

631

632 Material (1 specimen). 1ð̂, 11-12.xii.2019, Ankazobe District, Ambohitantely Reserve (1600 $633 \mathrm{~m}$ a.s.1.), S $18.1969^{\circ}$, E $47.2847^{\circ}$, lgt. $\mathrm{PP}$ (attracted by light).

634 Distribution (Fig. 2B)

635 This species is known from the few localities given by Griveaud (1964) (from north to south): 636 "Réserve Naturelle III" - present Parc National de Zahamena; Réserve Spéciale

637 d'Ambohitantely; La Mandraka - ca. 10 km S of Paysages Harmonieux Protégé du Complexe 638 Anjozorobe-Angavo; "Ampolomita" - east of Belanitra (for details see Griveaud, 1957);

639 Tsarafidy/Ankafina - about 32 km NNE of Fianarantsoa; "préfecture de Fianarantsoa" (not 
640 shown on the map, see remarks). Occurs between 800 and $1600 \mathrm{~m}$ elevation, Ambohitantely is

641 the highest recorded localisation.

642 Redescription of male genitalia (Fig. 5F)

643 Tegumen narrow, moderately sclerotised, not fused with vinculum, with a pair of lateral,

644 flattened protrusions, slightly curved dorso-distally and densely covered with short setae; uncus

645 base trapezoidal, recessed into distalo-dorsal wall of tegumen, surrounded laterally by short

646 tegumen arms; uncus prominent, bent ventrally, of arrowhead shape; narrowed in medial portion,

647 with dorsal, longitudinal rib in distal portion; subdorsally covered with long, erected setae

648 directed laterally; apex bulbous with round, concaved tip; vinculum narrow, tendril-like laterally,

649 produced medially into short, triangular, sharply terminated saccus; valva elongate, of claw-like

650 shape, narrowed in terminal half with sharp tip slightly curved inward, terminally with few

651 erected setae; costa at $1 / 3$ of its length with nodular protrusion, folded towards central,

652 membranous part of valva; sacculus sclerotised, reaching to the half of valvae length, with

653 erected setae on margin then in form of membranous, sclerotised, textured lobe, reaching nearly

654 till the end of valva, on outer margin with thin, erected setae; aedeagus massive, tubular,

655 widened basally, gradually narrowing towards termination; vesica membranous, tubular,

656 widened in basal portion, with longitudinal row of eight sharp, thick, spike-like cornuti bent

657 towards the base of vesica; terminal portion with a pair of adhered to each other, sclerotised

658 plates of subtriangular shape of which the outer one much larger than the inner one.

\section{Remarks}

660 Tritonaclia stephania was originally described and illustrated by Oberthür (1923: 135, pl. 566,

661 Fig. 4882) from southern Madagascar (Sud de Madagascar Reçu de M. Lamberton en Avril

662 1922), but he did not mention number nor sex of specimens. Generally, Charles Lamberton block

663 locality labels, and especially this one, are unreliable, even as to the part of the island (Viette,

664 [1962]: 15) as also seen for some butterflies so labelled which are expected only to occur in the

665 North (DCL, pers. obs.). However, the male specimen deposited now in NHMUK has a label

666 indicating a collecting locality agreeing with that given in the original description and another

667 label with information, that the specimen was a model for the illustration in the original

668 description. Griveaud (1964: 80, Figs 184-187) described the male and female genitalia and

669 designated the aforementioned male specimen (NHMUK010620988) from London as lectotype,

670 and another specimen (female) from MNHN, which he apparently recognized as a part of the

671 type series, as "neallotype". According to the labels both specimens were obtained from $\mathrm{Ch}$.

672 Lamberton in 1922, but collecting dates are unknown. However, Griveaud (1964) probably

673 recognized locality "Fianarantsoa" where the "neallotype" was collected as a very general area

674 and gave "préfecture de Fianarantsoa", which was a larger unit of the former administrative

675 division of Madagascar. For this reason, the locality is not shown on the map (Fig. 2B), but the

676 southernmost locality Tsarafidy is close to the city of Fianarantsoa, thus this exclusion does not

677 change the general range of the species significantly.

678 There are further 21 specimens deposited in MNHN, collected by P. Griveaud, P. Soga

679 and R. Vieu, and 20 specimens in PBZT, collected mostly by P. Griveaud. 
680

681

682

683

684

685

686

687

688

689

690

691

692

693

694

695

696

697

698

699

700

701

702

703

704

705

706

707

708

709

710

711

712

713

714

715

716

717

718

719

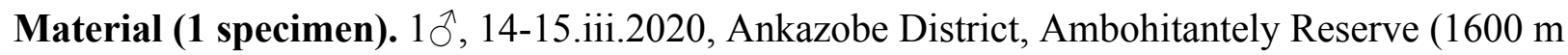
a.s.1.), S $18.1969^{\circ}$, E $47.2847^{\circ}$, lgt. ŁP (collected by netting at day).

\section{Distribution (Fig. 2C)}

The species is recorded for the first time from the Ambohitantely Reserve; it has so far been known from three localities (Griveaud, 1964) (from north to south): Antananarivo; Tsarafidy forest (erroneously written as "Tsarafify") - few kilometres W from Parc National de Ranomafana; "sous-préfecture de Midongy du Sud" - currently district Midongy du Sud, in large part overlapping with the Parc National de Befotaka-Midongy du Sud, that is marked on the map. Occurs at an elevation between 950 and $1600 \mathrm{~m}$.

\section{Redescription of male genitalia (Fig. 5C)}

Uncus short, subtriangular, at base with lateral indistinct protrusions dorsally covered with short erected setae directed outwards; apex ventrally provided with bulbous protrusion, terminated with claw-like hook incurved ventrally; valva short, suboval, dully terminated, without extended costal portion; costa and sacculus convex, in terminal portion costa with tiny shallow concavity; outer margin covered with several prominent, erected setae, distinctly longer than these on uncus; vesica membranous with numerous diverticuli and elongate, narrow, tubular ductus ejaculatorius; cornuti in form of multidimensional sclerotised block-like structure in median portion and single elongate sublateral sclerotisation originating close to vesica base and terminating in its distal third.

Contrary to the original description (Griveaud, 1964: 56, Figs 124-126) the major differences observed in two examined specimens can be summarized as follows (Fig. 5C): uncus not laterally flattened (uncus aplati latéralement), but rather three-dimensional due to ventral bulbous protrusion; valva without elongate costal portion as can be seen on Griveaud's Figs 124125 , but rather subsquare; sclerotised cornuti much more complicated and of different shape comparing to Fig. 126 where only single cornutus is visible.

\section{Remarks}

Tsarafidynia perpusilla with its red and black colouration is one of the most distinctive Malagasy Syntomini, hard to confuse with any other species. However, the original description of genitalia (Griveaud, 1964: 56, Figs 124-126) is schematic and these illustrations do little justice to their real appearance. Thus, here we redescribe the male genitalia basing on two specimens to make sure that observed differences are not a result of intraspecific variation.

The species has been described by Mabille ([1880])) as "Aglaope ? perpusilla", doubtfully placed in the Zygaenidae genus Aglaope Latreille, 1809. In the original description given in Latin the hindwing is divided into two colour zones, but both of them are described as "black" with the use of the same word, what does not tell them apart and is most probably a typo (Alae posticae margine antico usque ad medium alae nigro; caetera pars nigra est, fimbriaque nigra. Alae subtus similes. Corpus nigrum; antennae simplices, nigrae). Currently on the pin of the presumed holotype in NHMUK (NHMUK010354697), of about the right dimensions (about 
$72015.5 \mathrm{~mm}$ apex-apex, $16 \mathrm{~mm}$ maximum), there is a French-language handwritten label in the

721

722

723

724

725

726

727

728

729

730

731

732

733

734

735

736

737

738

739

740

741

742

743

744

745

746

747

748

749

750

751

752

753

754

755

756

757

758

759

writing style of $\mathrm{Ch}$. Oberthür notifying this fact: "Not in accordance with the description. Hindwings are indicated black in the description." (Pas conforme á la description. Les ailes inférieures sont indiquées noires dans la description). The labels "Madag" and "Aglaope perpusilla Mab." also attached to this specimen are in a script consistent for P. Mabille. There is no part of the description in French, except that Mabille writes: "đ̄, 17 mill...Un mâle (coll. H.G. Smith). Concinna species, sedis incertae". Jordan (1928) was the first who mentioned this issue in a publication and proposed that the outer hindwing zone should had been referred as "vitreous" (pars vitrea), but he did not see the holotype and guessed that it had gone missing. This may rise from the fact that the type specimens of many species described by P. Mabille have been unrecognized for a long time, as only rarely being directly labelled by him. Viette \& Fletcher (1968) finally localised what they considered to be the holotype of A. perpusilla in NHMUK. Rothschild (1911) independently described the species as Micronaclia bicolor basing on one female (holotype) and two males collected in Antananarivo by Chulliat. This locality, long devoid of native forest, apparently was not confirmed by Griveaud (1964), and is mentioned separately and in quotation mark. Conspecifity of Aglaope perpusilla and Micronaclia bicolor was, according to Viette (1965), established first in the collection of MNHN by H. de Toulgoët, and then published by Griveaud (1964), who created a separate genus Tsarafidynia for it. Therein, the outer zone of the hindwing should have been referred as red or carmine (certainly not black nor vitreous!) in the original description. The type species of Aglaope, Sphinx infausta Linnaeus, 1767 (Zygaenidae - see also Viette, 1965) which has pectinate antennae and is patterned just like the presumed type of Aglaope perpusilla, black with the basal part of hindwing red. It is likely for this reason alone that Mabille's description was simply inaccurate, while he wrote the identity label correctly; more likely he meant to write caetera pars rubra est, and the second use of black in the same sentence in any case makes no logical sense.

Holotypes of Tsarafidynia perpusilla and Micronaclia bicolor are deposited in NHMUK London. There are further 15 specimens in MNHN and 35 in PBZT. In these collections are also specimens collected in 1970s., so few years after the monograph of Griveaud (1964) and range of the species needs to be reassessed including all the specimens.

\section{Discussion}

\section{Significance of Réserve Spéciale d'Ambohitantely as a local centre of diversity of Malagasy Syntomini and in protection of the biodiversity of Madagascar}

Madagascar is one of the world's most rich biodiversity hotspots (Ganzhorn et al., 2001) with a very high levels of endemism (Goodman \& Benstead, 2005), attributed to long lasting isolation from other continents and explosive evolutionary radiations (Dewar \& Richard, 2007; Yoder \& Nowak, 2006). An illuminative example of such a radiation within Lepidoptera is the endemic Malagasy lineage of the tribe Syntomini (Przybyłowicz et al., 2019). In the Réserve Spéciale

Peer) reviewing PDF | (2021:03:59387:1:1:NEW 27 May 2021) 
760

761

762

763

764

765

766

767

768

769

770

771

772

773

774

775

776

777

778

779

780

781

782

783

784

785

786

787

788

789

790

791

792

793

794

795

796

797

798

799

d'Ambohitantely eight species in four genera have been recorded, and five of them are known so far only from this place. This means that $5 \%$ of total species-level diversity (Viette, 1990) of the group is currently recorded just from less than two thousand hectares of forest, making the Reserve a centre of the local diversity of Syntomini.

Our results provide further evidence for importance of this Reserve, comprising ones of the last considerable fragments of forest in the whole Central Plateau of Madagascar (Ratsirarson et al., 2003), as an important complement for preservation of the whole remaining biodiversity of Madagascar. The uniqueness of the area is so far emphasized by three endemic plants and three endemic frog species (Goodman, Raherilalao \& Wohlhauser, 2018). Also, in terms of phylogeography the reserve conserves unique genetic diversity in otherwise widespread species of butterflies (Linares et al., 2009). At the same time, the biodiversity of this place is still not fully documented, especially regarding arthropods. Here we recorded two Syntomini species new for Ambohitantely. In the last few years, several taxa new to science have been described from the Reserve: four species of subsocial Anelosimus spiders (Agnarrson et al., 2015), mite Atropacarus distinctus Niedbała \& Starý, 2014, and two rove beetles: Squamiger elegans Hlavác \& Baňař, 2016 and Ambohitantella banari Hlaváč \& Nakládal, 2016, with a new genus created for the latter species.

The montane moist evergreen forest present in Ambohitantely, as well as its floristic and faunistic species composition indicate close affinities with the region of eastern Madagascar (Langrand, 2003; Gautier et al., 2018). Syntomini of the Reserve also match this pattern, as the three more widely distributed species, Maculonaclia ankasoka, Tritonaclia stephania and Tsarafidynia perpusilla, are known from several localities in the eastern and central Madagascar (Griveaud, 1964), and Ambohitantely is one of the northern- and westernmost (Fig. 2), and all these localities share the same general type of forest (Gautier et al., 2018). This is also the case in another arctiine genus, Cyana in the Lithosiini (Karisch, 2013; Volynkin, 2020). As the highest diversity of Syntomini species occurs in the longitudinal zone of tropical forests extending throughout the eastern part of the island (Lees, Kremen \& Andriamampianina, 1999), it is possible that the entire Syntomini fauna present in the area of Ambohitantely derives from the so called "eastern" forests.

Knowledge on the distribution of Malagasy insects, including Lepidoptera, is still far incomplete, selective and biased towards protected and easily accessible areas (Iannella, D'Alessandro \& Biondi, 2019). Malaise trap studies have started to show a remarkable level of previously unknown diversity, even in one of the best studied reserves, Parc National d'Analamazoatra [= "Andasibe"], notably among the micromoths (Lopez-Vaamonde et al., 2019). However, considering all published records (Griveaud, 1964; 1966; 1969; 1970; 1972; [1974]; Viette, 1987), we can infer that that the distribution of Syntomini in the area east from Ambohitantely has been studied far more intensively than other regions of the island. An exception for areas readily accessible from the capital is Paysages Harmonieux Protégé du Complexe Anjozorobe-Angavo ("Anjozorobe"), where the fauna of syntomines is still poor studied (DCL pers. obs.). This still forested part of the Angavo Massif is the first major patch of

Peer) reviewing PDF | (2021:03:59387:1:1:NEW 27 May 2021) 
800 forest encountered eastwards of Ambohitantely (ca. $90 \mathrm{~km} \mathrm{E}$ as the crow flies). Therefore, in 801 terms of understanding the past forest connectedness of Ambohitantely, more intense efforts 802 should be made to examine this area. For example, Tritonaclia stephania was already recorded at 803 a similar elevation along the once unfragmented Angavo Massif, at La Mandraka (Griveaud, 804 1964). It may turn out that ranges of at least part of the Syntomini species known only from 805 Ambohitantely are wider than currently known, and they are not actually endemic to the area. 806 Moreover, it is supposed that forests of Ambohitantely and Anjozorobe-Angavo were connected 807 to each other only a few hundred years ago (Rakotondravony \& Goodman, 1998 in Goodman \& 808 Raherilalao, 2003), but there is no direct evidence when the separation occurred, and it was most 809 probably before 1900 (see Linares et al., 2009) if not long before. Rather surprisingly in this 810 context, results of Linares et al. (2009) suggest that Ambohitantely has remained as an isolated 811 patch of forest long enough for genetic drift to fix a unique COI haplotype in three species of 812 Heteropsis butterflies occurring in the Reserve. Although the also dense forest restricted riodinid 813 Saribia tepahi (Boisduval, 1833) exhibited a similar haplotype to Tsaratanana (Linares et al., 8142009 ), $450 \mathrm{~km}$ to the north, perhaps suggesting that a forest connection northwards may have 815 existed within the time of human colonisation.

816 The current landscape of the Central Plateau and its most recent past, especially yet in 817 historical times, has been widely debated since the 19th century. Ambohitantely, as one of the 818 last remnants of forest in the Central Plateau, is of particular interest in such speculations. Three 819 main approaches to the past of the Central Highlands can be distinguished, as summarized in 820 Yoder et al. (2016): the "forest", "grassland" and "mosaic" hypotheses. Recent studies, not only 821 botanical, but also those on distribution of mouse lemur species, support the latter one. This 822 assumes that landscape composed of patches of forest and grassland had been existing in the 823 High Plateau long before human arrival, in cycles of isolation and reconnection of forest 824 fragments driven by climate, and with a rapid fragmentation and separation from the eastern 825 rainforests near the last glacial maximum (Yoder et al., 2016 and papers cited therein; Joseph \& 826 Seymour, 2020; Tiley et al., 2020). In that light, referring to the forest fragments of 827 Ambohitantely as "relict" is not quite correct if it alleges Ambohitantely was part of an extensive 828 and continuous former dense tropical forest (Klein, 2004). Despite this, the "lost paradise" line of 829 thinking, connected with the "forest" hypothesis promoted by the French colonizers at the end of 830 19th century (but see Grandidier, 1898) is still present, influencing discussions on the 831 environmental policy on Madagascar (Pollini, 2010; Amelot, 2017).

832 However, it is undeniable that current deforestation and fragmentation of the forest is 833 primarily anthropogenic (S.M. Goodman, 2021, unpublished data). The danger to

834 Ambohitantely's main forest block of fires set up in the adjacent grasslands has been at least 835 partly mitigated by installed firebreaks (Goodman, Raherilalao \& Wohlhauser, 2018). However, 836 direct deforestation, the second main threat for Ambohitantely, is still increasing at alarming 837 rates, and concerns also forest within the borders of the Reserve. Between 2010 and 2017 alone, 838 over 400 ha of forest disappeared in the Reserve and adjacent areas, while rate of natural forest 
839 regeneration since 1949 up to 2017 was virtually negligible. This has caused not only decrease of 840 forest coverage, but also its further fragmentation (S.M. Goodman, 2021, unpublished data).

841

842

843

844

845

846

847

848

849

850

851

852

853

854

855

856

857

858

859

860

861

862

863

864

865

866

867

868

869

870

871

872

873

874

875

876

877

878

Effects of this fragmentation in Ambohitantely have already been studied on:

herpetofauna (Vallan, 2000), birds (Langrand \& Wilmé, 1997) and insectivorous mammals (Goodman \& Rakotondravony, 2000), but to our knowledge it has never been addressed in regard invertebrates (except in the context of phylogeography of butterflies: Linares et al., 2009). According to our observations, Malagasy syntomines are rather sedentary species, and do not fly between forest fragments, and thus their relatively abundant fauna can make Ambohitantely an excellent site for the future studies on the mobility of species belonging to this group, as well as potential impact of forest fragmentation on their populations. An especially suitable model could be Thyrosticta dilata with its behaviour, rather unusual among Malagasy Syntomini, of being lured to light in large number of individuals. During our study, 40 of total 45 specimens were attracted in this way. Moreover, all of them were trapped within the forest, and no individual was recorded in the shrubby vegetation of the ecotone (Fig. 1D) nor collected by a light trap set in the grassland, ca. $100 \mathrm{~m}$ from the forest's edge (Fig. 1B).

As already mentioned, further investigation of the distribution of Syntomini in remnant patches of forest in the area of Central Plateau is crucial to understanding their overall patterns of distribution. Also research on biology of Madagascan Syntomini and their potential food resources may shed some light on their ecological connections with certain types of vegetation. At the same time, with five Syntomini species known so far only from Ambohitantely, it cannot be excluded that some of them will turn out indeed to be endemic for the area, as local endemism is characteristic for many evolutionary lineages within the fauna of Madagascar (Wilmé, Goodman \& Ganzhorn, 2006), also within arthropods, spectacularly so for example among the giant pill millipedes (Wesener, 2009), dung beetles (Knopp et al., 2011) or mayflies (Benstead et al., 2003). Up until now several hypotheses have been proposed to explain these unique patterns of distribution, but they were addressed mostly to vertebrates and results show that in many cases a pluralistic approach is required rather than emphasis on a single environmental factor (Wilmé, Goodman \& Ganzhorn, 2006; Pearson \& Raxworthy, 2009; Vences et al., 2009).

\section{Polymorphism of males of Thyrosticta dilata}

We described here a yellow morphotype of Thyrosticta dilata, omitted by Griveaud (1964) in the original description. This species possesses two discrete forms with continuous variation between individuals within each of them. A similar example from the tribe Arctiini is recently described in the Amazonian species Watsonidia fulgida Grados, 2019, where both males and females represent two separate morphotypes within one species, but with continuous variation in male genitalia among specimens of both morphotypes. As for W. fulgida (Grados, 2019), the intraspecific variation in Thyrosticta dilata is not related to any sexual dimorphism (indeed the female remains unknown), nor to geographic, environmental or seasonal dimorphism, because specimens of both types were collected simultaneously in the same place, and moreover the 
879 species is known only from the Ambohitantely Reserve. Other, but more phylogenetically distant 880 examples in Lepidoptera are: the Asian clearwing moth Bembecia rushana Gorbunov, 1992 with 881 two differently coloured morphotypes and the African nymphalid Euphaedra eberti Aurivillius, 882 1896, with two significantly different wing patterns. In both cases, genetic and morphological 883 analyses confirmed conspecifity of the forms (Zúbrik et al., 2019; Garrevoet et al., 2013). 884 However, causes of variation in all three abovementioned species remain unknown (Grados, 885 2019; Zúbrik et al., 2019; Garrevoet et al., 2013).

886 As common in Arctiinae moths (Simmons, 2009), nearly all members of Malagasy 887 Syntomini, including Thyrosticta dilata, are aposematically coloured. They usually have black, 888 brown or ochraceous wings as background with white, yellow, orangish-ochraceous and hyaline 889

890 spots, up to nearly transparent wings, a few species loosely resembling wasps, and often possess

891

892

893

894

895

896

897

898

899

900

901

902

903

904

905

906

907

908

909

910

911

912

\section{Conclusions}

914 Our results contribute to an adequate description of diversity of Malagasy Syntomini, indicating 915 that the Réserve Spéciale d'Ambohitantely is a centre of local richness of the group, about $63 \%$ 916 of which appear also to be endemic there. It provides further evidence for importance of the area

917 in protection of the remaining biodiversity of Madagascar. It also highlights the Malagasy 
918 Syntomini, whose early stage biology is as yet completely unknown, as an important new study

919 system for the study of adaptive radiation in relation to the diversification of colour pattern.

920

921

922

923

924

925

926

927

928

929

930

931

932

933

934

935

936

937

938

939

940

941

942

943

944

945

946

947

948

949

950

951

952

953

954

955

956

957

\section{Acknowledgements}

We are grateful to Niklas Wahlberg for help with molecular studies, Steven Goodman for providing data from his manuscript in revision and a shapefile with the borders of protected areas of Madagascar, Anna Przystałkowska for graphic processing of figures, Michał Grzyska for consultations of French-language texts, and Joël Minet (MNHN) for a query about a publication date and on previous occasions facilitating access to the MNHN collection (likewise Alberto Zilli and Geoff Martin for access to the NHMUK collection).We thank to MICET

(Antananarivo) staff, especially Tiana Vololontiana and Benjamin Andriamihaja for their excellent logistic support and for arranging our permits, students Jimmy Rakotonirina and Hakimou Mahamoudou for help in collecting specimens, Vincent Razafindranaivo (University of Antananarivo) for efficiently arranging the University component of our permit conditions and Balsama Rajemison (PBZT/CAS) and her collection supervisor for access to the Lepidoptera collection and Brian Fisher and the local staff of CAS for helping with logistics of equipment. We thank our drivers and rangers working at the Réserve Spéciale d'Ambohitantely for very reliably facilitating the fieldwork and alerting us about the forthcoming global pandemic before the closure of the Madagascar border just days after the end of this fieldwork. Finally we are grateful to three reviewers for valuable comments on the paper.

\section{References}

Abraham J-P, Benja R, Randrianasolo M, Ganzhorn JU, Jeannoda V, Leigh Jr. EG. 1996. Tree diversity on small plots in Madagascar: A preliminary review. Revue d'Écologie 51(2): 93-116.

Agnarsson I, Jencik B, Veve G, Hanitriniaina S, Agostini D, Goh S, Pruitt J, Kuntner M. 2015. Systematics of the Madagascar Anelosimus spiders: remarkable local richness and endemism, and dual colonization from the Americas. ZooKeys 509: 13-52 DOI: 10.3897/zookeys.509.8897.

Amelot X. 2017. Dire la Nature à Madagascar: des mythes contre des cartes. In: Combeau Y, Gallat T, Rolland Y, eds. Dire l'océan Indien, volume 1. Saint-Denis de La Réunion, OSOI/Université de La Réunion-Epica Edition, 32-53.

Aurivillius P. 1896. Diagnosen neuer Lepidopteren aus dem Congo-Gebiete. Öfversigt af Kongl. Vetenskaps-Akademiens Förhlhandlingar 53: 431-436.

Benstead JP, De Rham PH, Gattolliat J-L, Gibon F-M, Loiselle PV, Sartori M, Sparks JS, Stiassny MLJ. 2003. Conserving Madagascar's Freshwater Biodiversity. BioScience 53(11): 1101-1111 DOI: 10.1641/0006-3568(2003)053[1101:CMFB]2.0.CO;2.

Peer) reviewing PDF | (2021:03:59387:1:1:NEW 27 May 2021) 
958

959

960

961

962

963

964

965

966

967

968

969

970

971

972

973

974

975

976

977

978

979

980

981

982

983

984

985

986

987

988

989

990

991

992

993

994

995

996 Goodman SM, Benstead J. 2005. Updated estimates of biotic diversity and endemism for

997

Boisduval JBA. 1833. [Mémoire sur les Lépidoptères de Madagascar, Bourbon et Maurice].

Nouvelles Annales du Muséum d'Histoire Naturelle 2(2): 149-270.

Boisduval JBA. 1847. Catalogue des Lépidoptères recueillis par M. Delegorgue pendant les années 1838-1844 à Port Natal, au pays des Amazoulous et dans la contrée de Massilicatzi. In: Delegorgue A, ed. Voyage dans l'Afrique australe 1838-1844. Paris, 2, 585-602.

Brehm G. 2017. A new LED lamp for the collection of nocturnal Lepidoptera and a spectral comparison of light-trapping lamps. Nota Lepidopterologica 40(1): 87-108. DOI:

10.3897/nl.40.11887

Briolat ES, Burdfield-Steel ER, Paul SC, Rönkä KH, Seymoure BM, Stankowich T, Stuckert AMM. 2019. Diversity in warning coloration: selective paradox or the norm? Biological Reviews 94(2): 388-414 DOI: 10.1111/brv.12460.

de Joannis J. 1906. Description de Lépidoptères nouveaux de L'Ile Maurice. Annales de la Société entomologique de France 75: 169-183.

De Prins J, De Prins W. 2011-2019. Afromoths, online database of Afrotropical moth species (Lepidoptera). Available at http://www.afromoths.net (accessed 04 February 2021).

Dewar RE, Richard AF. 2007. Evolution in the hypervariable environment of Madagascar. Proceedings of the National Academy of Sciences 104(34): 13723-13727 DOI: 10.1073/pnas.0704346104.

Ganzhorn JU, Lowry II PP, Schatz GE, Sommer S. 2001. The biodiversity of Madagascar: one of the world's hottest hotspots on its way out. Oryx 35(4): 346-348 DOI: 10.1046/j.13653008.2001.00201.x.

Garrevoet T, Bartsch D, Lingenhöle A. 2013. On the knowledge of Bembecia rushana Gorbunov, 1992 and some related species (Lepidoptera: Sesiidae). Nota Lepidopterologica 36(2): 95-108.

Gautier L, Tahinarivony JA, Ranirison P, Wohlhauser S. 2018. Vegetation. In: Goodman SM, Raherilalao MJ, Wohlhauser S, eds. The terrestrial protected areas of Madagascar: their history, description and biota. Antananarivo: Association Vahatra, 207-242.

Madagascar. Oryx 39(1): 73-77 DOI: 10.1017/S0030605305000128.

Peer] reviewing PDF | (2021:03:59387:1:1:NEW 27 May 2021) 
998

999 Goodman SM, Raherilalao MJ. 2003. Effects of Forest Fragmentation on Bird Communities. In:

1000 Goodman SM, Raherilalao MJ, Wohlhauser S, eds. The Natural History of Madagascar.

1001 Chicago, London: The University of Chicago Press, 1064-1066.

1002

1003 Goodman SM, Raherilalao MJ, Wohlhauser S, eds. 2018. The terrestrial protected areas of

1004 Madagascar: Their history, description and biota. Antananarivo: Association Vahatra.

1005

1006

1007

1008

1009

1010

1011

1012

1013

1014

1015

1016

1017

1018

1019

1020

1021

1022

1023

1024

1025

1026

1027

1028

1029

1030

1031

1032

1033

1034

1035

1036

Goodman SM, Rakotondravony D. 2000. The effects of forest fragmentation and isolation on insectivorous small mammals (Lipotyphla) on the Central High Plateau of Madagascar. Journal of Zoology 250(2): 193-200 DOI: 10.1111/j.1469-7998.2000.tb01069.x.

Goodman SM, Duplantier J-M, Rakotomalaza PJ, Raselimanana AP, Rasoloarison RM, Ravokatra M, Soarimalala V, Wilmé L. 1998. Inventaire biologique de la forêt d'Ankazomivady, Ambositra. Akon'ny Ala 24: 19-32.

Gorbunov OG. 1992. Two new species of the genus Bembecia Hübner, 1819 from Middle Asia (Lepidoptera, Sesiidae). Atalanta 23: 249-253.

Grados J. 2019. A new species of the genus Watsonidia Toulgoët, 1981 (Lepidoptera, Erebidae, Arctiini): example of polymorphism in the Amazon of Peru. Zootaxa 4691(1): 33-46 DOI:

10.11646/zootaxa.4691.1.2

Grandidier A. 1898. Le boisement de 1'Imerina. Bulletin du Comité de Madagascar 4: 83-87.

Griveaud P. 1957. Premières observations sur les chasses entomologiques nocturnes à la lumière à Madagascar. Le Naturaliste Malgache 9(1): 147-152.

Griveaud P. 1964. Insectes Lépidoptères Amatidae. Faune de Madagascar 17: 1-147.

Griveaud P. 1966. Amatidae nouveaux de Madagascar [Lep.]. Bulletin de la Société entomologique de France 71: 7-8.

Griveaud P. 1969. Amatidae nouveaux ou peu connus de Madagascar [Lep.]. Bulletin de Madagascar 274: 277-294.

Griveaud P. 1970. Lépidoptères Amatidae récoltés dans le massif du Tsaratanana (Madagascar Nord). Mémoires ORSTOM 37: 205-206. 
1037 Griveaud P. 1972. Nouvelles espèces d'Amatidae de Madagascar [Lep.]. Bulletin de la Société

1038

1039

1040

1041

1042

1043

1044

1045

1046

1047

1048

1049

1050

1051

1052

1053

1054

1055

1056

1057

1058

1059

1060

1061

1062

1063

1064

1065

1066

1067

1068

1069

1070

1071

1072

1073

1074

1075

1076

entomologique de France 77: 289-292.

Griveaud P. [1974] Contribution à l'étude des Lépidoptères Hétérocères du massif de l'Andringitra (Madagascar Centre) RCP 225 - Campagne 1970-1971 (Insecta Lepidoptera Sphingidae, Saturniidae, Amatidae, Lymantriidae). Bulletin du Muséum national d'Histoire naturelle, Zoologie (1973) 125: 1461-1483.

Hall TA. 1999. BioEdit: a user-friendly biological sequence alignment editor and analysis program for Windows 95/98/NT. Nucleic Acids Symposium Series 41: 95-98.

Hlaváč P, Baňař P. 2016. The Pselaphinae (Coleoptera: Staphylinidae) of Madagascar. V. Description of Squamiger elegans gen. et sp. nov. from Central Madagascar. Zootaxa 4127(2): 393-400 DOI: 10.11646/zootaxa.4127.2.11.

Hlaváč P, Nakládal O. 2016. The Pselaphinae (Coleoptera: Staphylinidae) of Madagascar. VI. Description of Ambohitantella banari gen. et sp. n. with notes on Nearticerodes Jeannel, 1954 and Triceratomerus Jeannel, 1960. Zootaxa 4189(1): 183-188 DOI: 10.11646/zootaxa.4189.1.11

Iannella M, D’Alessandro P, Biondi M. 2019. Entomological knowledge in Madagascar by GBIF datasets: estimates on the coverage and possible biases (Insecta). Fragmenta Entomologica 51(1): 1-10 DOI: 10.4081/fe.2019.329.

Jordan K. 1928. On some Lepidoptera of special interest, with remarks on morphology and nomenclature. Novitates Zoologicae 34: 132-146.

Joseph GS, Seymour CL. 2020. Madagascan highlands: originally woodland and forest containing endemic grasses, not grazing-adapted grassland. Procedings of the Royal Society $B$ 287: 20201956 DOI: 10.1098/rspb.2020.1956.

Karisch T. 2013. Taxonomic revision of the African Cyana-species (Lepidoptera: Arctiidae, Lithosiinae). Esperiana 18: 39-197.

Klein J. 2004. Fiddling while Madagascar burns. Deforestation discourses and highland history. Norsk Geografisk Tidsskrift-Norwegian Journal of Geography 58(1): 11-22 DOI: 10.1080/00291950410004366.

Knopp T, Rahagalala P, Miinala M, Hanski I. 2011. Current geographical ranges of Malagasy dung beetles are not delimited by large rivers. Journal of Biogeography 38: 1098-1108 DOI: 10.1111/j.1365-2699.2010.02463.x.

Peer) reviewing PDF | (2021:03:59387:1:1:NEW 27 May 2021) 
Koda N. 1987. A generic classification of the subfamily Arctiinae of the Palaearctic and oriental

1079 regions based on the male and female genitalia (Lepidoptera, Arctiidae). Part I. Tyo to Ga 38(3):

1080 153-237 DOI: 10.18984/lepid.38.3_153.

1081

Kull CA. 2012. Air photo evidence of historical land cover change in the highlands: Wetlands

1083 and grasslands give way to crops and woodlots. Madagascar Conservation \& Development 7(3):

1084 144-152 DOI: $10.4314 /$ mcd.v7i3.7.

1085

1086

Kumar S, Stecher G, Li M, Knyaz C, Tamura K. 2018. MEGA X: Molecular Evolutionary

1087

Genetics Analysis across computing platforms. Molecular Biology and Evolution 35(6): $1547-$

1088 1549 DOI: 10.1093/molbev/msy096.

1089

1090

Langrand O. 1995. The Effects of Forest Fragmentation on Bird Species in Madagascar: A Case

1091 Study from Ambohitantely Forest Reserve on the Central High Plateau. MS Thesis, University of

1092 Natal, Pietermaritzburg.

1093

1094

Langrand O. 2003. Réserve Spéciale d'Ambohitantely. In: Goodman SM, Benstead JP, eds. The

1095

Natural History of Madagascar. Chicago, London: The University of Chicago Press, 1472-1476.

1096

1097

Langrand O, Wilmé L. 1997. Effects of forest fragmentation on extinction patterns of the

1098 endemic avifauna on the Central High Plateau of Madagascar. In: Goodman SM, Patterson BD,

1099 eds. Natural change and human impact in Madagascar. Washington, DC: Smithsonian

1100 Institution Press, 280-305.

1101

Latreille PA. 1809. Genera crustaceorum et insectorum secundum ordinem naturalem in familias disposita, iconibus, exemplisque plumiris explicata 4: 1-399.

1104

Lees DC, Kremen C, Andriamampianina L. 1999. A null model for species richness gradients: bounded range overlap of butterflies and other rainforest endemics in Madagascar. Biological Journal of the Linnean Society 67: 529-584 DOI: 10.1111/j.1095-8312.1999.tb01945.x.

Lees DC, Minet J. 2003. Lepidoptera: Systematics and Diversity. In: Goodman SM, Benstead JP, eds. The Natural History of Madagascar. Chicago, London: The University of Chicago Press, 748-761.

1112

Liebert T, Brakefield, P. 1990. The genetics of colour polymorphism in the aposematic Jersey 
1116 Linares M, Soto-Calderón I. Lees DC, Anthony N. 2009. High mitochondrial diversity in 1117 geographically widespread butterflies of Madagascar: A test of the DNA barcoding approach. 1118 Molecular Phylogenetics and Evolution 50(3): 485-495 DOI: 10.1016/j.ympev.2008.11.008.

1119

1120

1121

1122

1123

1124

1125

1126

1127

1128

1129

1130

1131

1132

1133

1134

1135

1136

1137

1138

1139

1140

1141

1142

1143

1144

1145

1146

1147

1148

1149

1150

1151

1152

1153

1154

Linnaeus C. 1767. Systema Naturae. Editio Duodecima Reformata. Tom I, Pars II. Holmiae: Impensis Direct. Laurentii Salvii, 533-1327.

Lopez-Vaamonde C, Sire L, Rasmussen B, Rougerie R, Wieser C, Ahamadi A, Minet J, Dewaard J, Decaëns T, Lees D. 2019. DNA barcodes reveal deeply neglected diversity and numerous invasions of micromoths in Madagascar. Genome 62(3): 108-121 DOI: 10.1139/gen2018-0065.

Mabille P. [1880]. Recensement des Lépidoptères Hétérocères observés jusqu'à ce jour à Madagascar. Annales de la Société entomologique de France (1879) 9: 291-348.

Miller JS. 1991. Cladistics and classification of the Notodontidae (Lepidoptera: Noctuoidea) based on larval and adult morphology. Bulletin of the American Museum of Natural History 204: $1-230$.

Minh BQ, Nguyen MAT, von Haeseler A. 2013. Ultrafast Approximation for Phylogenetic Bootstrap. Molecular Biology and Evolution 30(5): 1188-1195 DOI: 10.1093/molbev/mst024.

Mittermeier RA, Louis Jr. EE, Richardson M, Schwitzer C, Langrand O, Rylands AB, Hawkins F, Rajaobelina S, Ratsimbazafy J, Rasoloarison R, Roos C, Kappeler PM Mackinnon J. 2010. Lemurs of Madagascar. Third Edition. Conservation International.

Moraes SS, Cardoso L, Brandao K, Duarte M. 2016. Extreme sexual dimorphism and polymorphism in two species of the tiger moth genus Dysschema (Lepidoptera: Erebidae): association between males and females, sexual mimicry and melanism revealed by integrative taxonomy. Systematics and Biodiversity 15(3): 1-15 DOI: 10.1080/14772000.2016.1250835.

Nguyen L-T, Schmidt HA, von Haeseler A, Minh BQ. 2015. IQ-TREE: A Fast and Effective Stochastic Algorithm for Estimating Maximum-Likelihood Phylogenies. Molecular Biology and Evolution 32(1): 268-274 DOI: 10.1093/molbev/msu300.

Niedbała W, Starý J. 2014. New species of Atropacarus (Hoplophorella), (Acari, Oribatida, Phthiracaridae) from the Afrotropical Region. Zootaxa, 3774(1): 74-82. DOI:

10.11646/zootaxa.3774.1.5

Peer) reviewing PDF | (2021:03:59387:1:1:NEW 27 May 2021) 
1155 Oberthür C. 1923. Lépidoptères de Madagascar et d'Afrique tropicale. Etudes de

1156 Lépidoptérologie comparée 21: 119-155.

1157

1158

1159

1160

1161

1162

1163

1164

1165

1166

1167

1168

1169

1170

1171

1172

1173

1174

1175

1176

1177

1178

1179

1180

1181

1182

1183

1184

1185

1186

1187

1188

1189

1190

1191

1192

1193

1194

Pearson RG, Raxworthy CJ. 2009. The evolution of local endemism in Madagascar: watershed versus climatic gradient hypotheses evaluated by null biogeographic models. Evolution 63(4): 959-967 DOI: 10.1111/j.1558-5646.2008.00596.x.

Peña C, Malm T. 2012. VoSeq: a voucher and DNA sequence web application. PLoS One 7: e39071 DOI:10.1371/journal.pone.0039071.

Poda N. 1761. Insecta Musei Graecensis, quae in ordines, genera et species juxta Systema Naturae Caroli Linnaei digessit. Typis Haeredum Widmanstadii.

Pollini J. 2010. Environmental degradation narratives in Madagascar: From colonial hegemonies to humanist revisionism. Geoforum 41(5): 711-722 DOI: 10.1016/j.geoforum.2010.04.001.

Przybyłowicz Ł, Lees DC, Zenker MM, Wahlberg N. 2019. Molecular systematics of the arctiine tribe Syntomini (Lepidoptera, Erebidae). Systematic Entomology 44(3): 624-637. DOI:

$10.1111 /$ syen. 12343

Przybyłowicz Ł, Tarcz S. 2015. Strong sexual dimorphism unraveled by DNA analysis - towards a better understanding of Pseudothyretes classification (Lepidoptera: Erebidae: Arctiinae).

Zoological Journal of the Linnean Society 173(1): 22-54 DOI: 10.1111/zoj.12198.

Rakotondravony D, Goodman SM. 1998. Inventaire biologique, Forêt d'Andranomay, Anjozorobe. Recherches pour le Développement, série sciences biologiques 13: 1-110.

Ratsirarson J, Edwards ME, Olsson EGA, Armbruster WS, Pareliussen I, Réau B. 2003. Forest Restoration and Biodiversity Conservation in the Central Highlands: The Case of the Réserve Spéciale d'Ambohitantely. In: Goodman SM, Benstead JP, eds. The Natural History of Madagascar. Chicago, London: The University of Chicago Press, 1476-1480.

Rothschild W. 1911. New Syntomidae and Arctianae. Novitates Zoologicae 18: 154-158.

Simmons R. 2009. Adaptive coloration and mimicry. In: Conner WE, ed. Tiger Moths and Woolly Bears: Behavior, Ecology, and Evolution of the Arctiidae. Oxford University Press, 115126.

Solofondranohatra CL, Vorontsova MS, Hempson GP, Hackel J, Cable S, Vololoniaina J, Lehmann CER. 2020. Fire and grazing determined grasslands of central Madagascar represent

Peer) reviewing PDF | (2021:03:59387:1:1:NEW 27 May 2021) 
1195 ancient assemblages. Proceedings of the Royal Society B 287: 20200598 DOI:

$1196 \quad 10.1098 / \mathrm{rspb} .2020 .0598$.

1197

1198 Tiley GP, Blanco MB, Ralison JM, Rasoloarison RM, Stahlke AR, Hohenlohe PA, Yoder AD.

1199 Population genomic structure in Goodman's mouse lemur reveals long-standing separation of

1200 Madagascar's Central Highlands and eastern rainforests. bioRxiv 2020.01.30.923300 DOI:

1201 10.1101/2020.01.30.923300.

1202

1203

Trifinopoulos J, Nguyen L-T, von Haeseler A, Minh BQ. 2016. W-IQ-TREE: a fast online

1204

phylogenetic tool for maximum likelihood analysis. Nucleic Acids Research 44: W232-W235

1205

DOI: $10.1093 / \mathrm{nar} / \mathrm{gkw} 256$.

1206

1207

Twort VG, Minet J, Wheat CW, Wahlberg N. 2020. Museomics of a rare taxon: placing

1208

Whalleyanidae in the Lepidoptera Tree of Life. bioRxiv 2020.08.18.255182 DOI:

1209

$10.1101 / 2020.08 .18 .255182$.

1210

1211

Vallan D. 2000. Influence of forest fragmentation on amphibian diversity in the nature reserve of

1212 Ambohitantely, highland Madagascar. Biological Conservation 96(1): 31-43 DOI:

1213 10.1016/S0006-3207(00)00041-0

1214

1215

Vallan D. 2003. Consequences of Rain Forest Fragmentation for Herpetofauna: A Case Study

1216

1217

from Ambohitantely. In: Goodman SM, Benstead JP, eds. The Natural History of Madagascar.

1218

1219

1220

Chicago, London: The University of Chicago Press, 899-907.

Vences M, Wollenberg KC, Vieites DR, Lees DC. 2009. Madagascar as a model region of species diversification. Trends in Ecology \& Evolution 24(8): 456-465 DOI:

1221 10.1016/j.tree.2009.03.011.

1222

Viette P. [1962]. Noctuelles quadrifides de Madagascar nouvelles ou peu connues [lepidoptera].

1224

1225

1226

Mémoires de l'Institut scientifique de Madagascar (E) (1961) 12: 171-190.

1227

1228

1229

Viette P. 1965. Les Zygaenidae de Madagascar (Lep.). Bulletin mensuel de la Société linnéenne de Lyon, 34(4): 121-125 DOI: 10.3406/linly.1965.5760.

1230

1231

1232

1233

Viette P. 1987. Maculonaclia griveaudi n. sp., Nouveau Syntomide de Madagascar (Lepidoptera). Lambillionea 87(11-12): 135-136.

1234

Viette P. 1990. Faune de Madagascar. Supplément 1. Liste récapitulative des Lépidoptères Hétérocères de Madagascar. Privately published by the author. 
1235 Viette P, Fletcher DS. 1968. The types of Lepidoptera Heterocera described by P. Mabille.

1236

1237

1238

1239

1240

1241

1242

1243

1244

1245

1246

1247

1248

1249

1250

1251

1252

1253

1254

1255

1256

1257

1258

1259

1260

1261

1262

1263

1264

1265

1266

1267

1268

1269

1270

1271

1272

1273

1274

Bulletin of the British Museum of natural History (Entomology) 21: 389-425.

Volynkin AV. 2020, On the taxonomy of the subgenus Gigantovulpecula Karisch, 2013 of the genus Cyana Walker, 1854, with description of a new species (Lepidoptera: Erebidae Arctiinae: Lithosiini). Zootaxa 4861(3): 376-384 DOI: 10.11646/zootaxa.4861.3.4.

Wahlberg N, Wheat CW. 2008. Genomic Outposts Serve the Phylogenomic Pioneers: Designing Novel Nuclear Markers for Genomic DNA Extractions of Lepidoptera. Systematic Biology 57(2): 231-242 DOI:10.1080/10635150802033006.

Wesener T. 2009. Unexplored richness: discovery of 31 new species of Giant Pill-Millipedes endemic to Madagascar, with a special emphasis on microendemism (Diplopoda, Sphaerotheriida). Zootaxa 2097(1): 1-134. DOI: 10.11646/zootaxa.2097.1.1.

Wilmé L, Goodman SM, Ganzhorn JU. 2006. Biogeographic Evolution of Madagascar's Microendemic Biota. Science 312: 1063-1065 DOI: 10.1126/science.1122806.

Yoder A, Nowak M. 2006. Has Vicariance or Dispersal Been the Predominant Biogeographic Force in Madagascar? Only Time Will Tell. Annual Review of Ecology Evolution and Systematics 37: 405-431. DOI: 10.1146/annurev.ecolsys.37.091305.110239.

Yoder AD, Campbell CR, Blanco MB, dos Reis M, Ganzhorn JU, Goodman SM, Hunnicutt KE, Larsen PA, Kappeler PM, Rasoloarison RM, Ralison JM, Swofford DL, Weisrock DW. 2016. Geogenetics of Madagascar's mouse lemurs. Proceedings of the National Academy of Sciences 113(29): 8049-8056 DOI: 10.1073/pnas.1601081113.

Zenker MM., Wahlberg N, Brehm G, Teston JA, Przybyłowicz Ł, Pie MR, Freitas AVL. 2017. Systematics and origin of moths in the subfamily Arctiinae (Lepidoptera, Erebidae) in the Neotropical region. Zoologica Scripta 46(3): 348-362 DOI: 10.1111/zsc.12202.

Zhang J, Lees DC, Shen J, Cong Q, Huertas B, Martin G, Grishin NV. 2020. The mitogenome of a Malagasy butterfly Malaza fastuosus (Mabille, 1884) recovered from the holotype collected over 140 years ago adds support for a new subfamily of Hesperiidae (Lepidoptera). Genome 63(4): 195-202 DOI: 10.1139/gen-2019-0189.

Zúbrik M, Picq S, Oremans P, Nisole A, Tremblay S, Cusson M, Panigaj L', Mikitová B, Bollino M. 2019. Morphological and genetic diversity of two individual forms of Euphaedra eberti (Lepidoptera, Nymphalidae). African Invertebrates 60(2): 195-213 DOI:

10.3897/AfrInvertebr.60.35262.

Peer) reviewing PDF | (2021:03:59387:1:1:NEW 27 May 2021) 


\section{Figure 1}

Réserve Spéciale d'Ambohitantely.

(A) General localisation on Madagascar, black dot indicates the capital city Antananarivo, green dot - Ambohitantely Reserve. (B) Detailed map of the Reserve, remnant patches of forest marked in green, area of the Reserve hatched, red dot - the light trap setup point ca. $100 \mathrm{~m}$ from the forest edge, blue dot - the furthest point on the daytime transect, near the waterfall. (C) General view of the southern part of the Reserve, with the forest covering hilltops (in the middle and on the right side), while in surrounding areas it is constrained to valley bottoms (background), foreground covered with ferns being an important element of herbaceous vegetation in the area. (D) Intermediate zone of shrubby vegetation between grassland (foreground) and forest (background) occurring in some fragments of the Reserve. Map Data: @ 2021 Maxar Technologies, @ 2021 CNES/Airbus. Photo credit: Marcin Wiorek. 

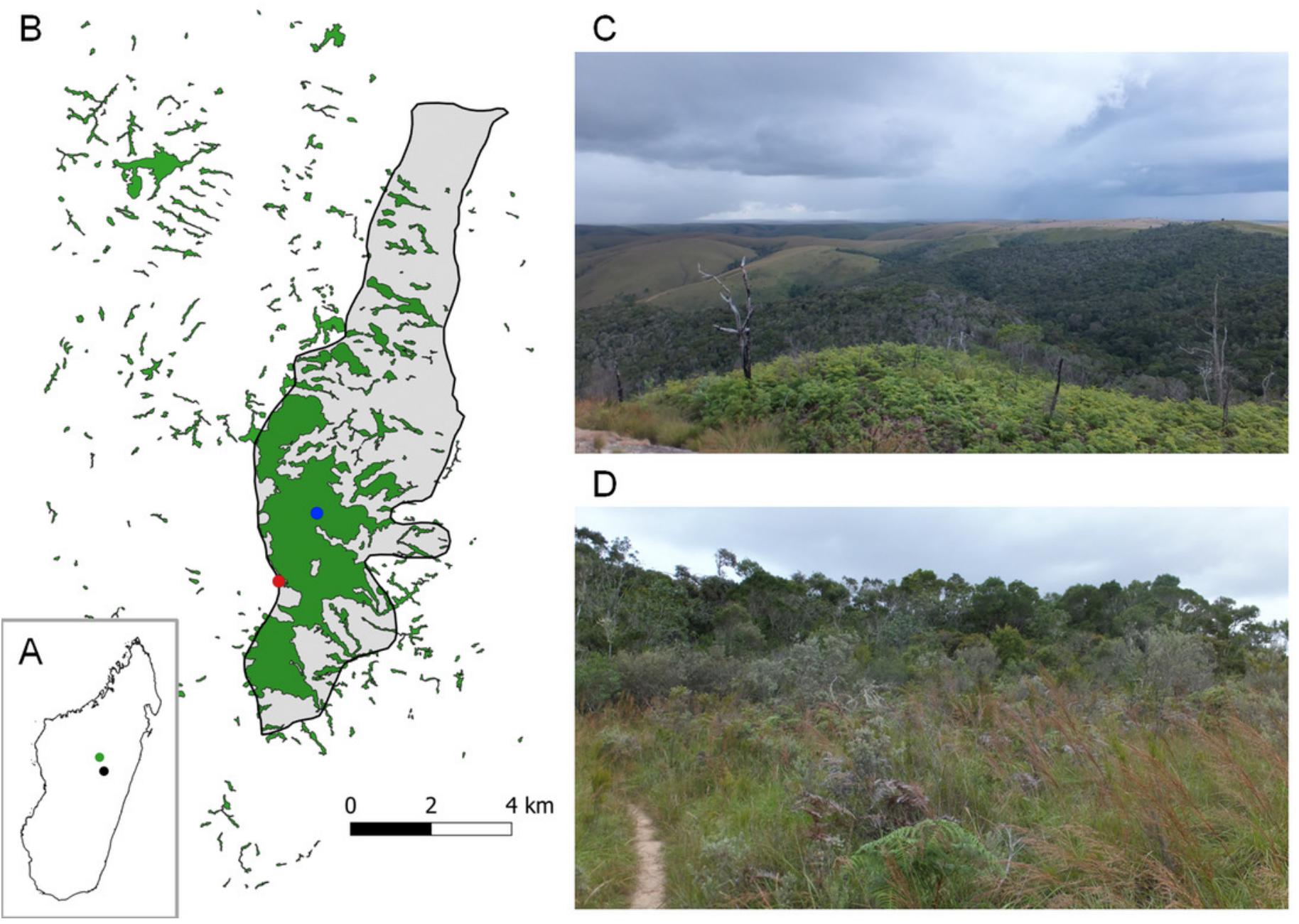


\section{Figure 2}

Records of widely distributed species occurring in the Réserve Spéciale d'Ambohitantely.

(A) Maculonaclia ankasoka. (B) Tritonaclia stephania. (C) Tsarafidynia perpusilla, red dot indicates Ambohitantely, blue dots - remaining localities listed in the text.
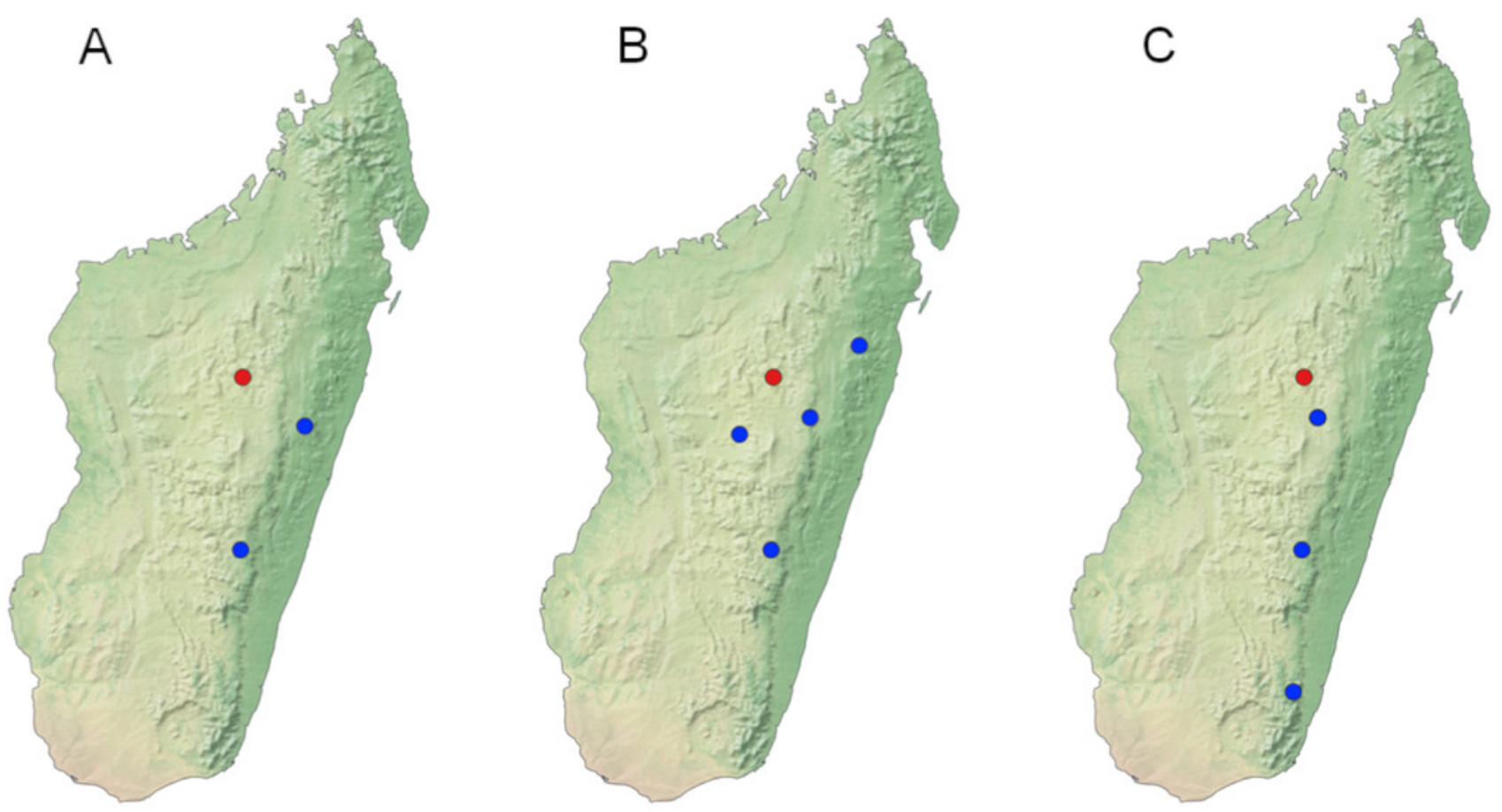
Figure 3

Syntomini of Ambohitantely, resting posture.

(A) Maculonaclia ankasoka, female. (B) Maculonaclia brevipenis, male. (C) Maculonaclia tampoketsya, female. (D) Thyrosticta vestigii, female. (E) Thyrosticta dilata, black morphotype, male. (F) Thyrosticta dilata, yellow morphotype, male. (G) Tritonaclia stephania, male. (H) Tsarafidynia perpusilla, male. 


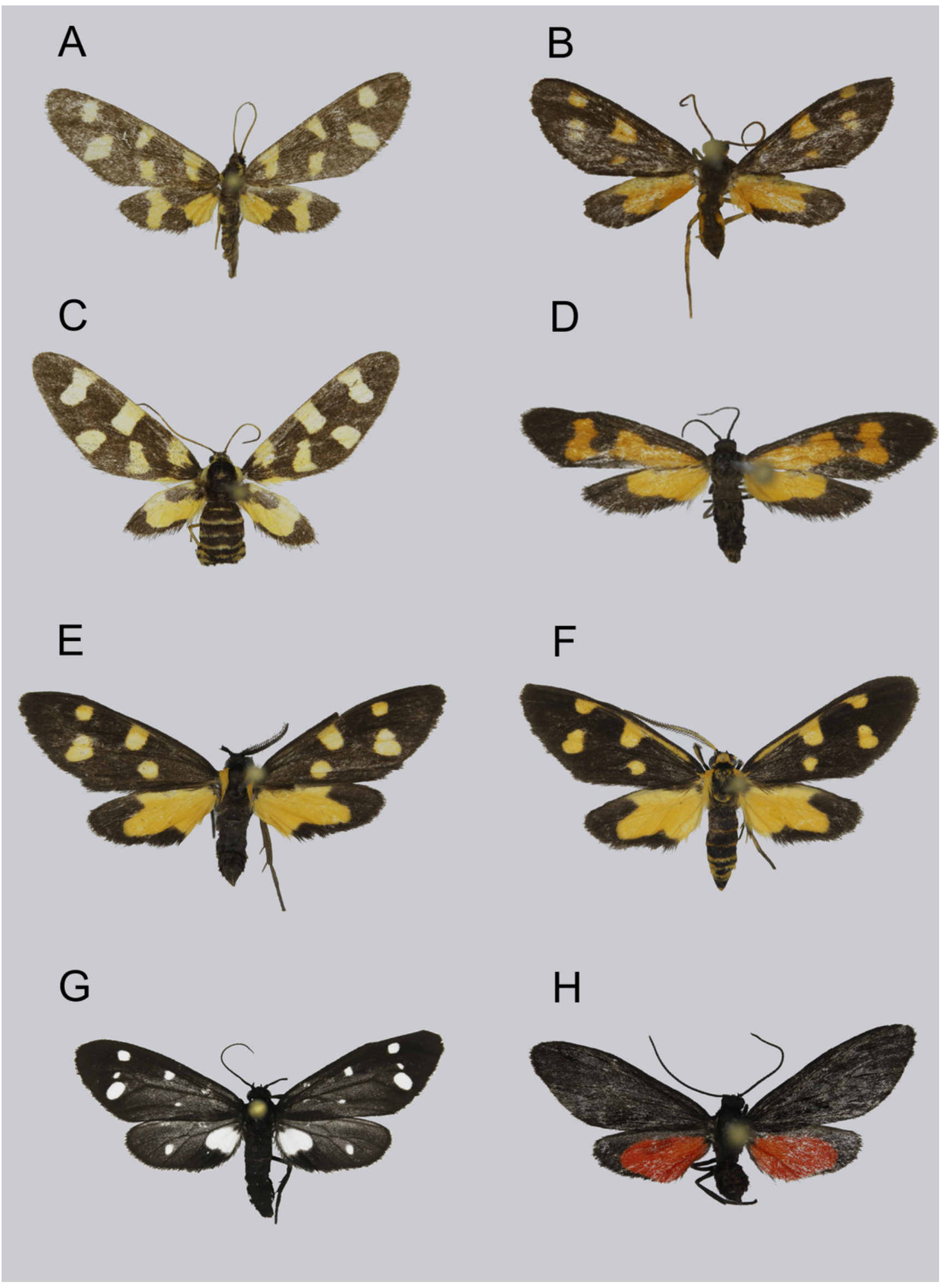


Figure 4

Female genitalia of Syntomini of Ambohitantely.

(A)Maculonaclia ankasoka. (B)Maculonaclia tampoketsya. (C)Thyrosticta vestigii.

A

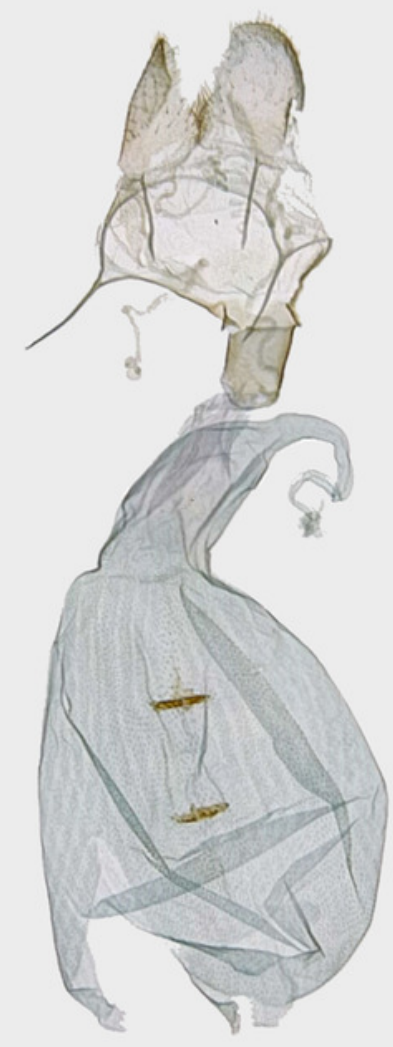

B

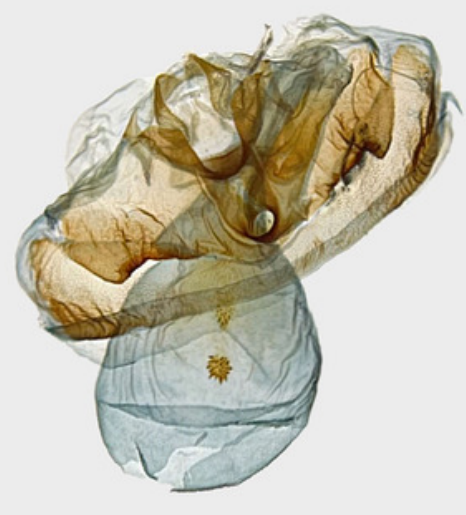

C

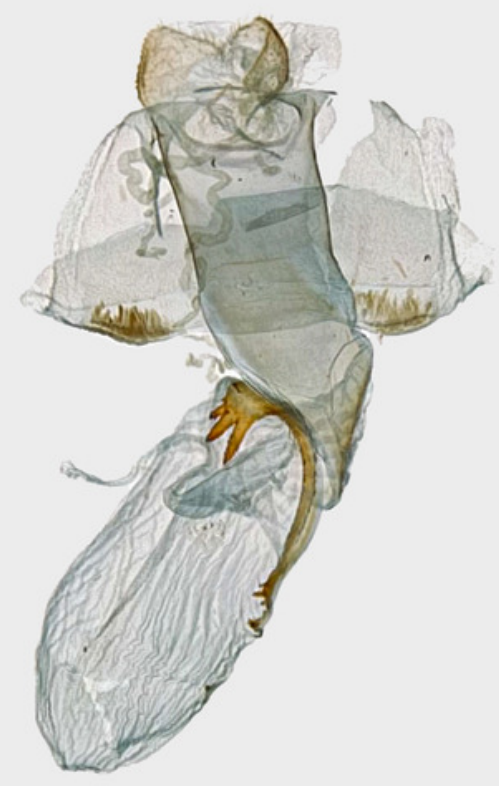




\section{Figure 5}

Male genitalia of Syntomini of Ambohitantely.

(A)Maculonaclia brevipenis. (B)Maculonaclia tampoketsya. (C)Tsarafidynia perpusilla.

(D)Thyrosticta dilata, yellow morphotype. (E)Thyrosticta dilata, black morphotype.

(F)Tritonaclia stephania.

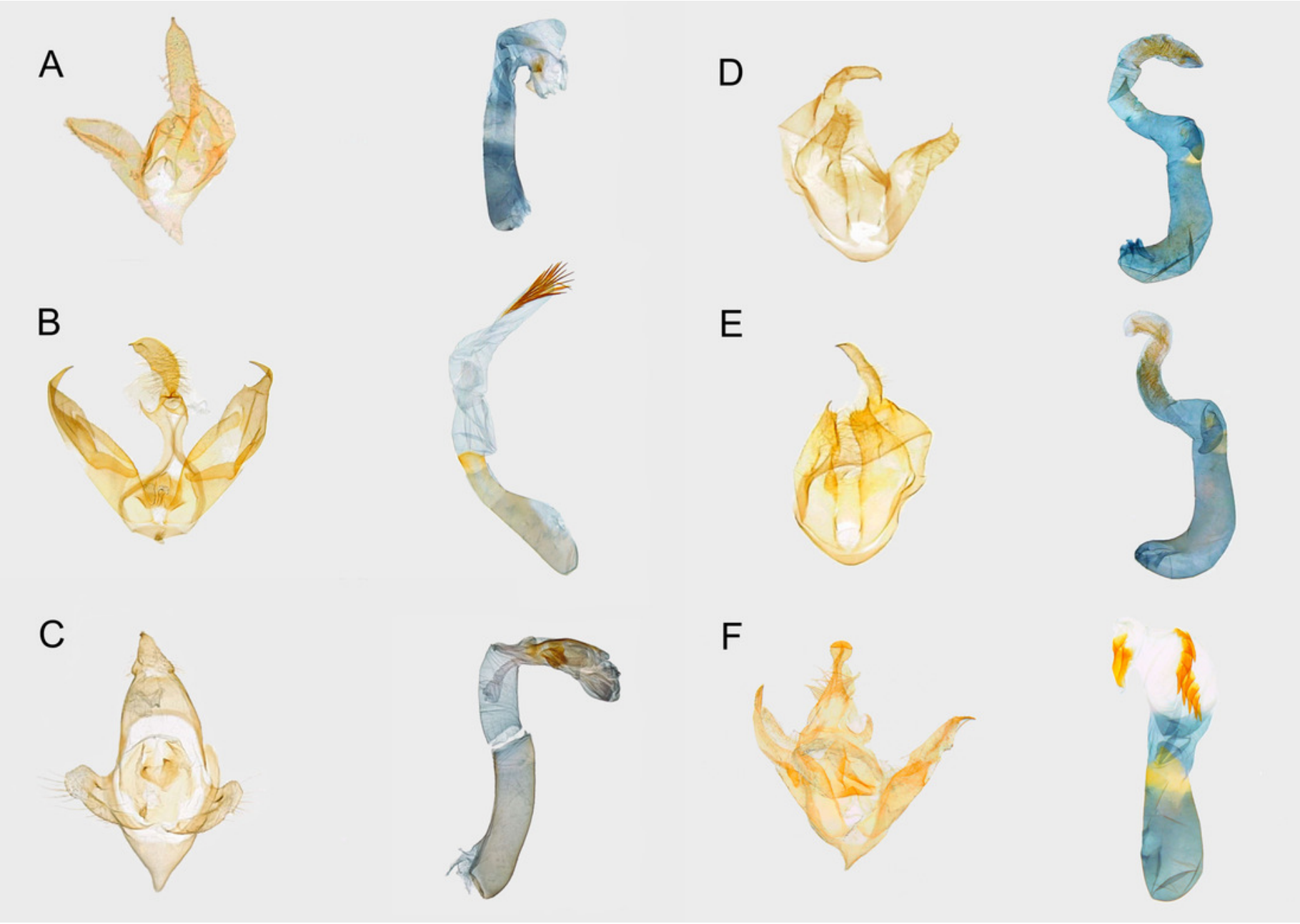




\section{Figure 6}

\section{Phylogenetic tree based on a Maximum Likelihood analysis of the barcode region.}

Yellow dots indicate yellow morphotype of $T$. dilata, black dots - black morphotype. Node labels - ultrafast bootstrap values (see Materials \& Methods), scale bar - number of substitutions per site.

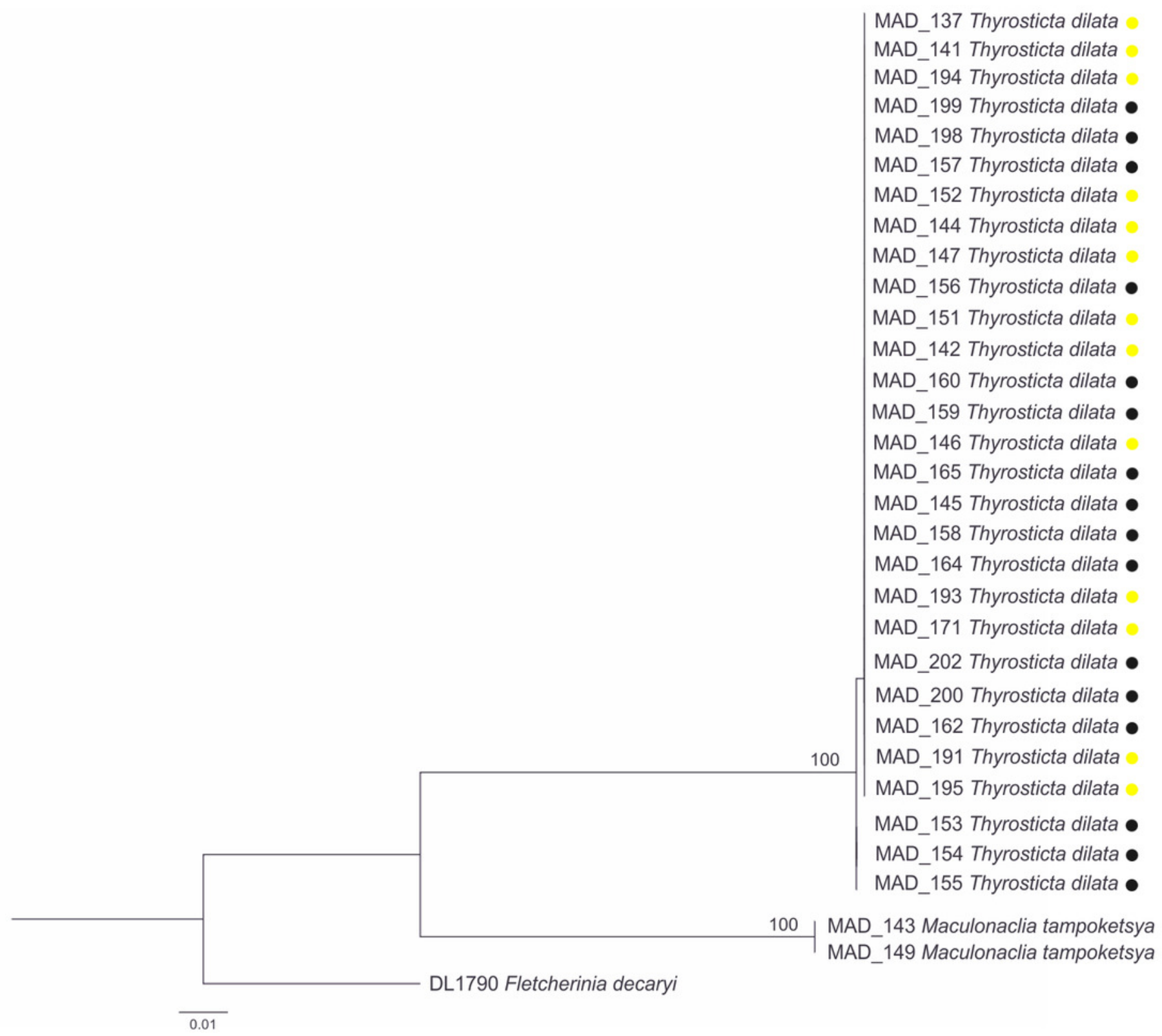

